\title{
THE EFFECT INTERLEAVING HAS ON THIN-PLY NON-CRIMP FABRIC LAMINATE IMPACT RESPONSE: X-RAY TOMOGRAPHY INVESTIGATION
}

\author{
S.M. García-Rodríguez ${ }^{1 *}$, J. Costa ${ }^{1}$, V. Singery ${ }^{2}$, I. Boada ${ }^{3}$, J.A. Mayugo ${ }^{1}$ \\ ${ }^{1}$ AMADE, Polytechnic School, University of Girona, Campus Montilivi s/n, 17003, Girona, \\ Spain \\ ${ }^{2}$ Chomarat, 39 Avenue de Chabannes, 07160, Le Cheylard, France \\ ${ }^{3}$ Departement of Informatics, Applied Mathematics and Statistics, University of Girona, \\ Campus Montilivi s/n, 17003, Girona Spain
}

\begin{abstract}
To improve the damage resistance and tolerance of thin laminates manufactured with thin-ply non-crimp-fabrics, we interleaved non-woven veils (two different types of co-polyamide veil were studied) into the interlaminar regions. We devised an impact, compression after impact (CAI) and quasi-static indentation experimental campaign, where $\mathrm{X}$-ray micro-computed tomography illustrated how: (a) matrix cracking, delamination and fibre failure interact during out-of-plane loading and (b) interleaving affects the thickness of the interface. One type of thermoplastic interlayer avoided resin accumulation, reduced the initiation of delamination and improved CAI strength by up to $28 \%$.
\end{abstract}

Keywords: B. Compression after impact; D. CT analysis; thin-ply; interleaving.

\section{Introduction}

In an effort to reduce costs, the airline industry is increasingly considering thinner carbon fibre reinforced composite laminates manufactured using cost-efficient resin infusion (RI) methods. Both facts accentuate the out-of-plane susceptibility of such types of components. For instance, bending stiffness decreases when laminate thickness is reduced [1] and RI is limited to low

\footnotetext{
${ }^{*}$ Corresponding author. Tel.: +34 972418817

Email addresses: sgarciarodriguez91@gmail.com (S.M. García-Rodríguez), josep.costa@udg.edu (J. Costa).
} 
viscosity resins that are inherently brittle [2]. In service, accidental strikes may reduce the loadcarrying capacity as a result of matrix cracking, delamination and fibre breakage [3,4].

New manufacturing approaches, such as the tow spreading method, allow plies thinner than 125 $\mu \mathrm{m}$ (so-called 'thin-plies') to be produced [5] and, in turn, these are attracting growing interest because in-situ strength is increased [6,7] and certain in-plane mechanical properties are improved [5,8-11]. During impact, matrix cracking and delamination are delayed in the thinplies [12,13]. Despite the evident contributions in terms of laminate strength, decreasing plythickness deteriorates the inter- and intra-laminar fracture toughness [14-16] and consequently, designing damage-tolerant components using thin-ply laminates requires the incorporation of toughening methods.

Many investigations have added toughening agents during the manufacturing process to improve the interlaminar fracture toughness. Reinforcements can be incorporated through-thethickness (e.g. Z-pins), mixed within the matrix (e.g. soluble rubber particles) or incorporated in the interlaminar regions (e.g. thermoplastic films) [17]. Yet other studies have hybridized carbon and glass to improve translaminar fracture toughness $[3,18]$. In our investigation, we focus on a relatively unexplored interlaminar toughening approach: interleaving with nonwoven veils [2]. We selected this type of additive because of its cost effectiveness, its suitability for RI and its potential to arrest delamination [2,17,19].

Walker et al. (2002) [20] interleaved polyamide (PA) veils in every interface of carbon/epoxy layups and found the thermoplastic webs were able to localise impact damage without any flexural stiffness deterioration. Nash et al. (2016) [17] toughened quasi-isotropic carbon/benzoxazine non-crimp fabric (NCF) laminates with non-woven PA veils. As the number of interleaved interfaces increased, the projected delamination area decreased and the specimens presented a lower difference between residual and undamaged compressive strength. 
Hogg (2005) [19] and Zhu (2012) [21] improved the CAI strength of carbon/epoxy laminates by interleaving different types of thermoplastic veils.

The objective of this investigation is to (a) understand the impact damage mechanisms of carbon/epoxy thin layups manufactured with thin-ply NCFs and (b) characterize the effect interleaving co-polyamide (CoPA) non-woven veils has on damage resistance and tolerance. We considered laminates thinner than the standard (i.e. approximately $2 \mathrm{~mm}$ rather than 4-6 mm [22]) because they are closer to the thickness of the skins currently used in aircraft components. NCFs also combine the perfect placement of the reinforcing fibres with an easy-to-handle, costeffective, automated fabrication, i.e. an ideal combination when manufacturing plies of reduced thickness [23]. We carried out low-velocity impact, quasi-static indentation (QSI) and compression after impact testing. Damage caused by impact and QSI was inspected through ultrasonic C-scans and X-Ray micro-computed tomography $(\mu \mathrm{CT})$. The latter provided comprehensive insights into the effect interleaving has on the pattern of impact damage.

\section{Materials and Methods}

\subsection{Materials}

We used T700 GC carbon in the form of bi-axial NCFs (C-PLY ${ }^{\mathrm{TM}}$ from Chomarat, material

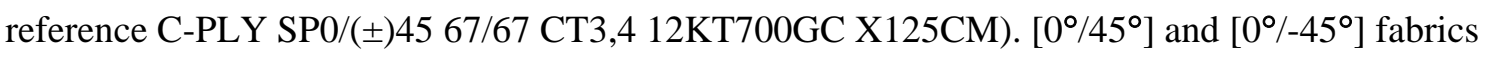
of $134 \mathrm{~g} / \mathrm{m}^{2}$ fibre areal weight (67 $\mathrm{g} / \mathrm{m}^{2}$ per unidirectional ply) were used. C-PLY YM fabrics were infused with HexFlow ${ }^{\circledR}$ RTM6 epoxy resin. 
Quasi-isotropic $[(45 / 0) /(-45 / 90)]_{4 s}$ laminates (THIN) were manufactured with the carbon C$\mathrm{PLY}^{\mathrm{TM}}$ reinforcement, where the bi-angle NCF layers are indicated by parenthesis.

Additionally, quasi-isotropic $\left[\left(45 / \mathrm{V}_{\mathrm{i}} / 0\right) / \mathrm{V}_{\mathrm{i}} /\left(-45 / \mathrm{V}_{\mathrm{i}} / 90\right) / \mathrm{V}_{\mathrm{i}}\right]_{4 s}(\mathrm{i}=1,2)$ laminates were considered: $\mathrm{V} 1$ and $\mathrm{V} 2 . \mathrm{V}_{1}$ and $\mathrm{V}_{2}$ were two confidential low-density web-like materials made of dispersed CoPA fibres ('non-woven veils'). Their melting point was higher $\left(\mathrm{V}_{1}\right)$ and lower $\left(\mathrm{V}_{2}\right)$ than the curing temperature. In addition, while they both had the same fibre areal weight ( $\left.4 \mathrm{~g} / \mathrm{m}^{2}\right), \mathrm{V}_{1}$ presented a more open-web architecture formed of fibres with a greater diameter than those of $\mathrm{V}_{2}$.

Laminates were manufactured using resin transfer moulding (RTM). A single interlayer was incorporated in every interlaminar region of interleaved systems (NB: Chomarat incorporated the veils between the carbon plies of the NCFs during the stitching process, whereas the rest of interleafs were cut/placed manually during the pre-forming). The layups were pre-formed in a vacuum hot-press set at $85{ }^{\circ} \mathrm{C}$ for $10 \mathrm{~min}$. Prior to infusion, the resin was degassed for $5 \mathrm{~min}$ in a vacuum oven set at $80^{\circ} \mathrm{C}$ and 900 mbar (absolute value). Afterwards, the resin was heated to $120^{\circ} \mathrm{C}$ and infused at low pressure (maximum of 8 bars) into the dry fabric preform, which had been previously placed on a heated aluminium mould. The infusion temperature, pressure and vacuum were controlled to ensure a resin flow of 20-30 g/min for $20 \mathrm{~min}$. To cure the resin, the mould was heated to $170{ }^{\circ} \mathrm{C}$ for $90 \mathrm{~min}$. During the first $30 \mathrm{~min}$ of curing, the heat was maintained along with the infusion pressure, which ceased for the remainder of the process. Once cooled, the laminates were removed from the tool and post-cured, i.e. heated from room temperature to $180{ }^{\circ} \mathrm{C}$ at $1{ }^{\circ} \mathrm{C} / \mathrm{min}$, followed by $120 \mathrm{~min}$ of dwell time, and then cooled to room temperature at $1{ }^{\circ} \mathrm{C} / \mathrm{min}$. The nominal laminate thickness of THIN, V1 and V2 was 2.14-2.2 mm. The fibre volume fraction of THIN was measured according to the standard EN 2564:1998 [24]. However, the interleaved specimens were kept in sulphuric acid until the polyamide veils were completely dissolved. In all cases, three specimens were considered per laminate type. The 
fibre volume fraction of THIN, V1 and V2 was 56.22 $\pm 0.96,52.63 \pm 0.6$ and $54.27 \pm 1.22 \%$, where \pm means standard deviation.

\subsection{Experimental tests}

Impact testing was performed in a CEAST Fractovis Plus 7536 drop-weight tower with a 16 mm diameter hemispherical impactor. Specimens $100 \mathrm{~mm}$ wide x $150 \mathrm{~mm}$ long were positioned over a metallic fixture base with a $75 \mathrm{~mm}$ x $125 \mathrm{~mm}$ rectangular cut-out and restrained with four rubber-tipped clamps. For further details of the test configuration, refer to González et al. (2014) [3]. From a preliminary study, the experiments were conducted at 10 and $14 \mathrm{~J}$ impact energy to ensure that a considerable amount of damage (i.e. development of visible back-face fibre breakage) occurred in the samples.

QSI tests were performed using an electromechanical MTS INSIGHT®100 testing machine with a $10 \mathrm{kN}$ load-cell. The same boundary conditions and hemispherical indenter were used during the impact and QSI experiments because the purpose of the latter was to imitate the sequence of damage mechanisms that take place during impact events [25-27]. Indentation was conducted at a rate of $0.5 \mathrm{~mm} / \mathrm{min}$ to avoid dynamic effects. The energy applied to the system was obtained by integrating the area below the force-displacement curve. Three specimens per material system were indented to a different deflection, defined as the displacement of the indenter during the test. The smaller deflections ( $d=4$ and $4.4 \mathrm{~mm}$ ) were chosen based on the onset of acoustic emissions heard during testing of the THIN baseline. The higher deflection (d= $5.24 \mathrm{~mm}$ ) was selected based on the load drop observed in the same material. These deflections resulted in energies of approximately 4, 5.5 and $8 \mathrm{~J}$. The combination of QSI displacements and impact energies provided insight into the damage initiation (QSI) and damage growth (impact).

CAI tests were performed using an electromechanical MTS INSIGHT ${ }^{\circledR} 300$ testing machine with a $300 \mathrm{kN}$ load cell. A non-standard CAI device based on the design from Remacha et al. (2015) 
[28] (Figure 1a) was manufactured. This fixture enabled the testing of laminates thinner than those recommended by the standard ASTM 7137/D7137M [22], which would otherwise fail by structural global buckling [28-30]. It consisted of two anti-buckling plates with equally spaced vertical ribs to stabilize the specimen on the vertical plane. The central rib included a cut-out to prevent any interference with the damaged zone, ensuring local buckling-induced failure and allowing for damage propagation during compression. A load rate of $0.5 \mathrm{~mm} / \mathrm{min}$ was considered.

The impact, QSI and CAI test matrix is presented in the Table 1. The entire campaign was performed at $23 \pm 2{ }^{\circ} \mathrm{C}$ temperature and $50 \pm 5 \%$ relative humidity in the mechanical testing laboratory at the University of Girona. The laboratory is ISO17025 and NADCAP (non-metallic materials) accredited.

\subsection{Damage inspection}

A small piece from each of the THIN, V1 and V2 laminates was embedded into a twocomponent epoxy and inspected using an epifluorescence microscope. Impacted and indented specimens were inspected using an OLYMPUS OMNI MX C-scan. The Pulso-Echo technique was employed using a $5 \mathrm{MHz}$ piezoelectric probe and a reflective glass submerged in distilled water.

Representative impacted specimens and each indented sample were inspected with $\mu \mathrm{CT}$. Besides this, non-damaged samples (10 mm wide x $20 \mathrm{~mm}$ long) were also inspected to assess the microstructure of the THIN, V1 and V2 specimens. The inspection equipment consisted of an X-Ray source (20 W and $5 \mu \mathrm{m}$ maximum power and focal spot) and a 2400 x 2400 pixel detector. Both were manufactured by HAMAMATSU and assembled by Novadep Scientific Instruments. Contrast agents (i.e. penetrant dies) were avoided to ensure that matrix cracking and delamination were observed regardless of their interconnection. Prior to inspection, 
indented specimens were cut (see Figure 1b) to reduce the aspect ratio of the cross-sections normal to the axis of rotation and thus improve the signal-to-noise ratio [31]. The inspection parameters are summarized in Table 2. In all cases, 1400 projections (3 integrations per projection) were acquired as the sample rotated over $360^{\circ}$. From a previous C-scan, it was decided to examine the entire damage scenario of the indented specimens. In the case of the impacted specimens, two inspections were carried out; one to capture the whole damaged area and the other to detail a representative region centred at the site of impact. In some cases, 2D slices were rendered in 3D using the medical software Starviewer [32].

[Figure 1 about here.]

\section{Results}

\subsection{Structural response}

Figure 2 presents the load-displacement curves of representative specimens impacted at 10 and $14 \mathrm{~J}$. All the materials exhibited a similar flexural stiffness until a local maximum was reached $\left(\mathrm{F}_{\mathrm{i}}\right)$, followed by a load drop and a change in the bending response. The value of $\mathrm{F}_{\mathrm{i}}$ oscillated between 3 and $3.3 \mathrm{kN}$ in all cases. In the THIN specimens, the force dropped approximately $21 \%$ relative to the local maximum. In contrast, interleaving reduced this value; in particular the V2 sample impacted at $10 \mathrm{~J}$ displayed the minimum drop (approximately 6\%).

[Figure 2 about here.]

Figure 3 compares the load-displacement curves of the indented and representative impacted specimens of a particular system. In all cases, the curves of the indented specimens overlapped each other at every incremental displacement level. The load on the THIN and V1 specimens was increased non-linearly until a local maximum was reached $\left(\mathrm{F}_{\mathrm{Q}}\right)$. This was followed by several load drops and a change in the bending stiffness (Figure 3d). In contrast, V2 exhibited a non-linear response followed by a small load-oscillation without concomitant reduction of the flexural stiffness (approximately $3.4 \mathrm{kN}$ in the zoomed region of the Figure 3d). 
The curves of the THIN specimens impacted at 10 and $14 \mathrm{~J}$ also overlapped each other (Figure 3a). However, the interleaved materials featured some scatter regarding the value and the deflection at which Fi occurred during 10 or $14 \mathrm{~J}$ impacts (Figure 3b and 3c). On the other hand, Fi and $\mathrm{F}_{\mathrm{Q}}$ (impact and QSI) agreed reasonably for the THIN and V1 specimens (Figure 3a and 3b). In V2, the load oscillation was $6 \%$ higher than Fi (average of samples impacted at 10 and $14 \mathrm{~J}$, Figure 3c). For this system, we observed that the severity of the load-drop reduced as the strain rate of the experiment decreased (i.e. between 6-10\% for impact and negligible for QSI at $\mathrm{d}=5.24 \mathrm{~mm}$ ). Table 3 summarizes the values of $\mathrm{Fi}, \mathrm{F}_{\mathrm{Q}}$ and the magnitude of the associated load drops developed during impact and indentation of THIN, V1 and V2 specimens.

[Figure 3 about here.]

[Table 3 about here.]

\subsection{Non-destructive inspection}

We performed time-of-flight (TOF) C-scans to evaluate the global profile of the damage, the distribution through-the-thickness, and the projected area (Figure 4a). Because of the TOF gate configuration, no depth-information was provided for the first $500 \mu \mathrm{m}$ below the centre of impact. Additionally, in the indented profiles that were concave enough, the ultrasonic wave may have dispersed and hidden part of the results (see white and grey regions of specimens impacted at $14 \mathrm{~J}$, Figure 4a).

Ultrasonic inspection of specimens indented at $\mathrm{d}=4$ and $\mathrm{d}=4.4 \mathrm{~mm}$ featured none or very small amounts of damage (Figure 4a). At $d=5.24 \mathrm{~mm}$, the interleaved samples presented a circular damage profile, whereas the profile of the THIN samples elongated in the longitudinal direction. Additionally, V2 exhibited the highest projected damage area with an approximate $70 \%$ increase in respect to the average between the THIN and V1 specimens (Figure 4b).

For the specimens impacted at 10 and $14 \mathrm{~J}$, the damage propagated largely below the mid-plane, leading to global profiles oriented at $0^{\circ}$, albeit with the expception of V1 impacted at $10 \mathrm{~J}$, 
which was oriented at $45^{\circ}$ (Figure 4a). At $10 \mathrm{~J}$, every material featured damage distributed through-the-thickness. At $14 \mathrm{~J}$, the THIN specimens exhibited more severe damage in the tophalf of the laminate than their interleaved counterparts. Meanwhile, V2 presented the lowest projected damaged area (up to 55\% lower than the THIN baseline, Figure 4b).

[Figure 4 about here.]

Figures 5 and 6 presents the microstructure of THIN, V1 and V2 laminates obtained with $\mu \mathrm{CT}$ and epifluorescence microscopy. In every system, inspection detected resin-accumulated areas (so-called resin pockets) dispersed throughout the volume of specimens. $V_{1}$ veils conserved their (after manufacturing) 'fibrous' architecture, increased the thickness of the interface between the plies and caused porosity within resin-rich areas (Figures $5 \mathrm{~b}$ and $6 \mathrm{a}$ ). In contrast, V2 specimens exhibited a greater number of resin accumulations than the THIN (in density and size) specimens and less porosity than the V1 laminates (Figure 5c). We observed that, during manufacturing, $\mathrm{V}_{2}$ veils agglomerated within resin pockets (Figure $6 \mathrm{~b}$ ).

[Figure 5 about here.]

[Figure 6 about here.]

$\mu \mathrm{CT}$ slices of specimens indented at $\mathrm{d}=4 \mathrm{~mm}$ illustrate the onset of damage propagation resulting from quasi-static indentation loading (Figure 7). In all cases, most of the damage was confined to under the mid-plane and propagated a few millimeters away from each side of the centre of impact. The THIN specimen exhibited several types of matrix cracking (see Figures 7a and 8), i.e. (i) are the $45^{\circ}$ cracks that propagate parallel to the fibre direction ('shear cracks' [33]), (ii) are the cracks initiated at fibre-free zones where the NCF yarn stitch two consecutive plies [34] and (iii) are the $90^{\circ}$ cracks induced by tensile stresses at the bottom-plies of the laminate ('tensile cracks’ [26]). Note that the latter observation was hindered by their narrow crack-opening. We also observed delaminations less than $1 \mathrm{~mm}$ wide propagating at the intersection between two matrix cracks (iv). The interleaved systems exhibited all the previous damage mechanisms, with V1 showing increased crack density and new forms of damage propagation (Figure 7b, 7c and 8). In V1, we also observed (v) cracks tunneling resin-rich areas 
and (vi) delaminations 1-2 mm long propagating away from the impact centre. Finally, V2 presented a higher density of cracks than the THIN laminate (Figure 7d).

[Figure 7 about here.]

[Figure 8 about here.]

Increasing the deflection of the THIN plate to $4.4 \mathrm{~mm}$ incremented both the crack-openings and density of tensile cracks (Figure 9a). In the V1 specimen indented at $\mathrm{d}=4.4 \mathrm{~mm}$, matrix cracks and matrix crack-induced delaminations ('MCID' [35]) extended through-the-thickness of the sample (Figure 9b). The bottom-ply of the plate featured fibre failure due to tensile stresses induced by bending. In contrast, V2 presented a high density of matrix cracks in the lower-half of the laminate along with delaminations 1-2 mm long propagating away from the impact centre (Figure 9c).

The THIN specimen indented at $\mathrm{d}=5.24 \mathrm{~mm}$ developed fibre failure (viii) in all the plies in the lower third of the laminate (Figure 10a). Additionally, matrix cracks and MCID extended from the bottom to the top of the plate (Figures 7a and 9-10a). V1 also presented localized fibre breakage accompanied by cracks/MCID (Figure 10b). In contrast, V2 limited fibre failure to the bottom-ply of the sample (Figure 10c). In this system, delaminations developed through-thethickness with a characteristic 'cone-shape’ [36], i.e. they grew larger at the bottom-half of the laminate. Besides this, we also observed irregular delamination propagation through resin-rich areas, i.e. formation of crack ligaments (Figure 10d).

[Figure 9 about here.]

[Figure 10 about here.]

The main difference in the damage scenario between the THIN specimens impacted at $10 \mathrm{~J}$ or indented at $\mathrm{d}=5.24 \mathrm{~mm}$ was that, during impact, fibre failure extended to all the plies within the boundaries of the contact zone (Figures 10a and 11a). Away from this region, fibre breakage localized under the mid-plane. V1 exhibited similar damage features to the THIN samples, albeit with slightly reduced severity (Figure 11b). In contrast, V2 limited fibre breakage to 
almost the bottom-half of the laminate and presented reduced delamination propagation (Figure 11c).

The THIN and V1 specimens impacted at $14 \mathrm{~J}$ presented catastrophic fibre breakage throughthe-thickness and delamination propagation largely away from each side of the centre of impact (Figure 12a and b). In contrast, V2 constrained most of the damage to a $2 \mathrm{~mm}$ wide region centred at the point of impact, where all the plies presented fibre failure without significant associated delamination (Figure 12c). Interestingly, in V2 the propagation of delaminations was induced during indentation, but not during impact events (Figures 10-12c).

[Figure 11 about here.]

[Figure 12 about here.]

\subsection{Compression after impact}

All the impacted coupons displayed the same failure mechanisms, local buckling at the impact site followed by damage propagation perpendicular to the applied load (Figure 13a). In contrast, the pristine samples presented through-the-width damage localized at the topmost clamping region, suggesting that global buckling occurred during compression [28]. Consequently, the CAI results of pristine specimens are considered to be of a lower strength threshold. Regarding the CAI strength of impacted specimens, V2 improved the residual strength of the baseline by $7 \%$ and $28 \%$ for 10 and $14 \mathrm{~J}$ (Figure $13 \mathrm{~b}$ ).

[Figure 13 about here.]

\section{Discussion}

\subsection{Effect interleaving has on the microstructure}

NCF laminates present resin pockets because the stitching deviates carbon tows from their uniform directions [34] (see 3D representation number (ii) in Figure 8). Focusing on the effect of interleaving, $\mathrm{V}_{1}$ veils conserve their 'fibre-like' integrity because their melting point is higher than the manufacturing temperature. Since the non-woven veils have a higher permeability than 
the tightly packed carbon tows, the resin accumulates at the interlayers (i.e. increases the interface thickness) and leads to voids [17]. In contrast, the melting temperature of $\mathrm{V}_{2}$ corresponds approximately to the RTM curing temperature. This type of veil melts partially/completely and diffuses with the resin during the infusion process, leading to an interface with non-increased thickness.

\subsection{Force-displacement curves}

The impact load-displacement curves of the THIN, V1 and V2 specimens' evidence that all systems exhibit a similar flexural stiffness (Figure 2). Walker et al. (2002) [20] observed a similar response when interleaving $2.2 \mathrm{~g} / \mathrm{m}^{2}$ PA veils at every interlayer. However, other studies considering $34 \mathrm{~g} / \mathrm{m}^{2}$ PA veils report penalties of approximately 20\% in flexural stiffness [17], highlighting the trade-off between areal weight and bending stiffness or other properties of the material [2].

We observed a single load-drop following Fi and a series of consecutive load-drops following $F_{Q}$ (Figures 2-3). Comparing the load-displacement curves in Figure 3 with the $\mu \mathrm{CT}$ slices in Figures 9-11, we conclude that $\mathrm{Fi}$ and $\mathrm{F}_{\mathrm{Q}}$ correspond to the development of fibre failure localized in the lower half of the specimen (in the specimen V2 indented at $\mathrm{d}=5.24 \mathrm{~mm}$, the load oscillation may correspond to fibre breakage at the bottom-ply, see Figure 10c).

Additionally, the magnitude of the load drop associated to Fi scales with the severity of the observed fibre fracture (Figure 2, Table 3, and Figures 11-12) [27].

The fact that the load-displacement curves of the THIN, V1 and V2 specimens exhibit a nonlinear behaviour until fibre damage occurs is a consequence of the aspect ratio of the plate (i.e. how the thickness compares with the rest of the dimensions [37]). The impact response of thick laminates is dominated by shear and delamination [38]. Accordingly, the load-displacement curve presents two consecutive load-drops, attributed respectively to the onset of delamination 
and to fibre failure processes [26,27,33]. In contrast, the response of thin laminates is dominated by bending and associated non-linear membrane effects, which reduce or suppress the evidence of delamination onset in the force-displacement curve (i.e. the first load-drop. See, for example, the load-displacement curves of the impacted/indented thin laminates studied by Sutherland et al. (2005) [38], Yokozeki et al. (2010) [13] and Abisset et al. (2016) [26]).

\subsection{Sequence of damage events}

Based on the $\mu \mathrm{CT}$ observations of the indented and impacted specimens (Figures 7a and 9-12a), the damage sequence of the THIN specimens is summarized as follows:

- development of multiple tensile cracks at the bottom-ply of the laminate,

- development of matrix cracks and induced delaminations up to $3 \mathrm{~mm}$ wide from the bottom to the top,

- fibre failure localized to the lower sublaminate groups,

- growth of bottom-up fibre failure and enlargement of existing delaminations.

This is in agreement with the damage sequence proposed by Yokozeki et al. (2010) [13], who considered carbon/toughened epoxy [45/0/-45/90] 70 4m ply-thick layups, and $2.2 \mathrm{~mm}$ total laminate thickness. Since bending dominates the out-of-plane response of thin laminates, damage starts at the bottom interfaces and extends progressively towards the top surface [36].

The effect of interleaving on the onset of damage clearly depends on how the veils modify the microstructure. V1 delaminated prematurely as the excess of resin counteracted the reinforcing mechanisms that $\mathrm{V}_{1}$ fibres were able to provide at the interfaces (i.e. fibre pull-out or plastic deformation [39,40]) (Figures 6a and 7c). In contrast, $V_{2}$ veils increase the density of fibre-free regions of the thin-ply baseline without modifying the thickness of the interface (Figures $5 \mathrm{c}$ and 
6b). Consequently, V2 presents a higher density of matrix cracks than THIN and delays the initiation of delaminations relative to V1 (Figure 7d).

\subsection{Structural response: damage resistance and damage tolerance}

From the C-scans, $\mu \mathrm{CT}$, and CAI tests of the impacted specimens, interleaving $\mathrm{V}_{2}$ veils arrests the initiation of delaminations during impact events and, probably, the propagation of damage during CAI experiments [19] (Figures 4 and 11-13), i.e. the impact damage resistance and tolerance is improved in V2. Nash et al. (2016) [41,42] reported that polyamide non-woven veils improve damage resistance and certain CAI properties because they increase mode I and II interlaminar fracture toughness.

V2 specimens indented at $\mathrm{d}=5.24 \mathrm{~mm}$ present large delaminations, contrary to their impacted counterparts (Figures 10c and 11c). Additionally, the severity of their load-drop decreases from 6-10\% during impact to negligible during indentation at $\mathrm{d}=5.24 \mathrm{~mm}$ (Table 3 and Figures 2 and 3d). Both facts indicate that, as the strain rate decreases, a higher proportion of energy dissipates through delamination propagation rather than through fibre failure. The reason why delaminations propagate at the lowest loading rate could be related to the micromechanisms of crack propagation. At low rates, the thermoplastic polymer has enough time to accommodate part of the stresses through viscoplastic deformation ('shear yielding' [43]). Then, successive crack 'ligaments' form when the crack front encounters a resin-rich area (Figure 10d). At higher loading rates, the thermoplastic become more brittle, reducing the initiation of delaminations and localizing the damage under the impactor (Figure 12c). Bull et al. (2015) [27] observed an analogous effect in particle-toughened carbon/epoxy laminates where thermoplastic particles bridged the crack tip during QSI but did not do so during impact experiments.

In view of our study, non-woven veils are promising and cost-effective candidates for improving the damage tolerance of carbon/epoxy aircraft components. Manufacturing layups 
with this type of toughening agent only requires one extra-step, cutting the veils and placing them between the carbon layers. In addition, the open structure of the interlayers allows the resin to flow through-the-thickness, as opposed to other conventional approaches (e.g. interleaving thermoplastic films) [2]. Apart from reducing impact damage, non-woven veils could be used as scarf repairs [44], to reduce delamination induced by pull-off loads or to improve the conductivity of the laminate (e.g. functionalizing the veils with silver nano-wires [45] or graphite/graphene particles [46]).

\section{Conclusions}

Thin laminates manufactured with thin-ply NCFs accumulate matrix cracking and delaminations 1-3 mm wide until fibre failure causes the damage to extend further. Interleaving $\mathrm{V}_{2}$ copolyamide non-woven veils at every interface arrest the onset of delamination and improve the damage tolerance of thin-ply NCF systems. The melting temperature of CoPA fibres plays a key role in the laminate's microstructure and impact performance. Veils that withstand the manufacturing temperature accumulate resin at the interfaces and reduce the effect of interleaving on damage resistance and CAI strength.

\section{Acknowledgments}

The authors thank Chomarat (Le Cheylard, France) for providing the materials for this study. They would also like to acknowledge the support from the Spanish government through the Ministerio de Economía y Competitividad contract MAT2015-69491-C3-1-R. The first author would also like to acknowledge the support received from Secretaria d'Universitats i Recerca del Departament d'Economia i Conexeiment de la Generalitat de Catalunya with the predoctoral grant 2016FI_B_00551, co-funded by the Fondo Social Europeo (FSE). 


\section{References}

[1] Shivakumar KN, Elber W, Illg W. Prediction of Impact Force and Duration Due to LowVelocity Impact on Circular Composite Laminates. J Appl Mech 1985;52:674-80. doi:10.1115/1.3169120.

[2] Nash NH, Young TM, McGrail PT, Stanley WF. Inclusion of a thermoplastic phase to improve impact and post-impact performances of carbon fibre reinforced thermosetting composites - A review. Mater Des 2015;85:582-97. doi:10.1016/j.matdes.2015.07.001.

[3] González E V., Maimí P, Sainz de Aja JR, Cruz P, Camanho PP. Effects of interply hybridization on the damage resistance and tolerance of composite laminates. Compos Struct 2014;108:319-31. doi:10.1016/j.compstruct.2013.09.037.

[4] González E V., Maimí P, Camanho PP, Lopes CS, Blanco N. Effects of ply clustering in laminated composite plates under low-velocity impact loading. Compos Sci Technol 2011;71:805-17. doi:10.1016/j.compscitech.2010.12.018.

[5] Sihn S, Kim RY, Kawabe K, Tsai SW. Experimental studies of thin-ply laminated composites. Compos Sci Technol 2007;67:996-1008.

doi:10.1016/j.compscitech.2006.06.008.

[6] Arteiro A, Catalanotti G, Melro AR, Linde P, Camanho PP. Micro-mechanical analysis of the in situ effect in polymer composite laminates. Compos Struct 2014;116:827-40. doi:10.1016/j.compstruct.2014.06.014.

[7] Arteiro A, Catalanotti G, Melro AR, Linde P, Camanho PP. Micro-mechanical analysis of the effect of ply thickness on the transverse compressive strength of polymer composites. Compos Part A Appl Sci Manuf 2015;79:127-37. doi:10.1016/j.compositesa.2015.09.015.

[8] Amacher R, Cugnoni J, Botsis J, Sorensen L, Smith W, Dransfeld C. Thin ply composites: Experimental characterization and modeling of size-effects. Compos Sci Technol 2014;101:121-32. doi:10.1016/j.compscitech.2014.06.027. 
[9] Guillamet G, Turon A, Costa J, Renart J, Linde P, Mayugo JA. Damage occurrence at edges of non-crimp-fabric thin-ply laminates under off-axis uniaxial loading. Compos Sci Technol 2014;98:44-50. doi:10.1016/j.compscitech.2014.04.014.

[10] Guillamet G, Turon A, Costa J, Linde P. A quick procedure to predict free-edge delamination in thin-ply laminates under tension. Eng Fract Mech 2016;168:28-39. doi:10.1016/j.engfracmech.2016.01.019.

[11] Yokozeki T, Aoki Y, Ogasawara T. Experimental characterization of strength and damage resistance properties of thin-ply carbon fiber/toughened epoxy laminates. Compos Struct 2008;82:382-9. doi:10.1016/j.compstruct.2007.01.015.

[12] Saito H, Morita M, Kawabe K, Kanesaki M, Takeuchi H, Tanaka M, et al. Effect of plythickness on impact damage morphology in CFRP laminates. J Reinf Plast Compos 2011;30:1097-106. doi:10.1177/0731684411416532.

[13] Yokozeki T, Kuroda A, Yoshimura A, Ogasawara T, Aoki T. Damage characterization in thin-ply composite laminates under out-of-plane transverse loadings. Compos Struct 2010;93:49-57. doi:10.1016/j.compstruct.2010.06.016.

[14] Frossard G, Cugnoni J, Gmür T, Botsis J. Mode I Interlaminar Fracture of Carbon Epoxy Laminates: Effects of Ply Thickness. Compos Part A Appl Sci Manuf 2016;91:1-8. doi:10.1016/j.compositesa.2016.09.009.

[15] Teixeira RF, Pinho ST, Robinson P. Thickness-dependence of the translaminar fracture toughness: Experimental study using thin-ply composites. Compos Part A Appl Sci Manuf 2016;90:33-44. doi:10.1016/j.compositesa.2016.05.031.

[16] Bullegas G, Pinho ST, Pimenta S. Engineering the translaminar fracture behaviour of thin-ply composites. Compos Sci Technol 2016;131:110-22. doi:10.1016/j.compscitech.2016.06.002.

[17] Nash NH, Young TM, Stanley WF. An investigation of the damage tolerance of carbon/Benzoxazine composites with a thermoplastic toughening interlayer. Compos Struct 2016;147:25-32. doi:10.1016/j.compstruct.2016.03.015. 
[18] Ortega A, Maimí P, González E V., Sainz de Aja JR, de la Escalera FM, Cruz P. Translaminar fracture toughness of interply hybrid laminates under tensile and compressive loads. Compos Sci Technol 2017;143:1-12. doi:10.1016/j.compscitech.2017.02.029.

[19] Hogg PJ. Toughening of thermosetting composites with thermoplastic fibres. Mater Sci Eng A 2005;412:97-103. doi:10.1016/j.msea.2005.08.028.

[20] Walker L, Sohn MS, Hu XZ. Improving impact resistance of carbon-fibre composites through interlaminar reinforcement. Compos - Part A Appl Sci Manuf 2002;33:893-902. doi:10.1016/S1359-835X(02)00010-6.

[21] Zhu L. Investigations on damage resistance of carbon fiber composite panels toughened using veils. Chinese J Aeronaut 2013;26:807-13. doi:10.1016/j.cja.2013.05.006.

[22] ASTM Standard D7137/D7137M-12, Standard Test Method for Compressive Residual Strength Properties of Damaged Polymer Matrix Composite Plates. ASTM International, West Conshohocken, PA, 2012. doi:10.1520/D7137_D7137M-12, www.astm.org.

[23] Papila M. Design of and with thin-ply non-crimp fabric (NCF) as building blocks for composites. Sci Eng Compos Mater 2016:1-16. doi:DOI 10.1515/secm-2015-0386.

[24] European standard DIN EN 2564, Aerospace series, Carbon fibre laminates, Determination of the fibre-, resin- and void contents, Deutsches Institut für Normung (DIN), Berlin, Germany, 1998. n.d.

[25] Wagih A, Maimí P, Blanco N, Costa J. A quasi-static indentation test to elucidate the sequence of damage events in low velocity impacts on composite laminates. Compos Part A Appl Sci Manuf 2016;82:180-9. doi:10.1016/j.compositesa.2015.11.041.

[26] Abisset E, Daghia F, Sun XC, Wisnom MR, Hallet SR. Interaction of inter- and intralaminar damage in scaled quasi-static indentation tests: Part 1 - Experiments. Compos Struct 2016;136:712-26. doi:10.1016/j.compstruct.2015.09.061.

[27] Bull DJ, Spearing SM, Sinclair I. Investigation of the response to low velocity impact and quasi-static indentation loading of particle-toughened carbon-fibre composite 
materials. Compos Part A Appl Sci Manuf 2015;74:38-46.

doi:10.1016/j.compositesa.2015.03.016.

[28] Remacha M, Sánchez-Sáez S, López-Romano B, Barbero E. A new device for determining the compression after impact strength in thin laminates. Compos Struct 2015;127:99-107. doi:10.1016/j.compstruct.2015.02.079.

[29] Abir MR, Tay TE, Ridha M, Lee HP. On the relationship between failure mechanism and compression after impact (CAI) strength in composites. Compos Struct 2017;182:242-50. doi:http://dx.doi.org/10.1016/j.compstruct.2017.09.038.

[30] Ghelli D, Minak G. Low velocity impact and compression after impact tests on thin carbon/epoxy laminates. Compos Part B Eng 2011;42:2067-79. doi:10.1016/j.compositesb.2011.04.017.

[31] O’Brien NS, Boardman RP, Sinclair I, Blumensath T. Recent advances in X-ray Conebeam Computed Laminography. J Xray Sci Technol 2016;24:691-707. doi:10.3233/XST-160581.

[32] Starviewer Medical Imaging Software, http://www.starviewer.udg.edu/ n.d.

[33] Wagih A, Maimí P, González EV, Blanco N, Sainz de Aja JR, de la Escalera FM, et al. Damage sequence in thin-ply composite laminates under out-of-plane loading. Compos Part A Appl Sci Manuf 2016;87:66-77. doi:10.1016/j.compositesa.2016.04.010.

[34] Verpoest I, Lomov SV. Virtual textile composites software WiseTex: Integration with micro-mechanical, permeability and structural analysis. Compos Sci Technol 2005;65:2563-74. doi:10.1016/j.compscitech.2005.05.031.

[35] Zubillaga L, Turon A, Renart J, Costa J, Linde P. An experimental study on matrix crack induced delamination in composite laminates. Compos Struct 2015;127:10-7. doi:10.1016/j.compstruct.2015.02.077.

[36] Abrate S. Impact on composite structures, www.cambridge.org/9780521473897. n.d.

[37] Timoshenko S, Woinowsky-Krieger S. Theory of Plates and Shells, Second Edition. McGraw-Hill book company. 1989. 
[38] Sutherland LS, Soares CG. Impact characterisation of low fibre-volume glass reinforced polyester circular laminated plates. Int J Impact Eng 2005;31:1-23.

doi:10.1016/j.ijimpeng.2003.11.006.

[39] Kuwata M, Hogg PJ. Interlaminar toughness of interleaved CFRP using non-woven veils: Part 1. Mode-I testing. Compos Part A Appl Sci Manuf 2011;42:1551-9. doi:10.1016/j.compositesa.2011.07.016.

[40] Kuwata M, Hogg PJ. Interlaminar toughness of interleaved CFRP using non-woven veils: Part 2. Mode-II testing. Compos Part A Appl Sci Manuf 2011;42:1560-70. doi:10.1016/j.compositesa.2011.07.017.

[41] Nash NH, Ray D, Young TM, Stanley WF. The influence of hydrothermal conditioning on the Mode-I, thermal and flexural properties of Carbon/Benzoxazine composites with a thermoplastic toughening interlayer. Compos Part A Appl Sci Manuf 2015;76:135-44. doi:10.1016/j.compositesa.2015.04.023.

[42] Nash NH, Young TM, Stanley WF. The influence of a thermoplastic toughening interlayer and hydrothermal conditioning on the Mode-II interlaminar fracture toughness of Carbon/Benzoxazine composites. Compos Part A Appl Sci Manuf 2016;81:111-20. doi:10.1016/j.compositesa.2015.11.010.

[43] Launey ME, Ritchie RO. On the Fracture Toughness of Advanced Materials. Adv Mater 2009;21:2103-10. doi:10.1002/adma.200803322.

[44] Tzetzis D, Hogg PJ. Bondline toughening of vacuum infused composite repairs. Compos Part A Appl Sci Manuf 2006;37:1239-51. doi:10.1016/j.compositesa.2005.09.008.

[45] Guo M, Yi X, Liu G, Liu L. Simultaneously increasing the electrical conductivity and fracture toughness of carbon-fiber composites by using silver nanowires-loaded interleaves. Compos Sci Technol 2014;97:27-33. doi:10.1016/j.compscitech.2014.03.020.

[46] Barjasteh E, Sutanto C, Reddy T, Vinh J. A graphene/graphite-based conductive polyamide 12 interlayer for increasing the fracture toughness and conductivity of carbon- 
fiber composites. J Compos Mater 2017;0:1-9. doi:10.1177/0021998317705707. 
Figure captions

Figure 1a) Non-standard compression after impact (CAI) test fixture (adopted from [32]). 1b) Cutting of indented specimens prior to inspection with $\mu C T$.

Figure 2. Load-displacement curves of representative THIN, V1 and V2 specimens impacted at a) $10 \mathrm{~J}$ and b) $14 \mathrm{~J}$. For colour interpretation refer to online version of this manuscript.

Figure 3. Load-displacement curves of representative impacted and indented specimens a) THIN b) V1 c) V2. 3d) Load-displacement curves of indented THIN, V1 and V2 specimens indented at $d=$ $5.24 \mathrm{~mm}$. For colour interpretation refer to online version of this manuscript.

Figure 4a) Ultrasonic C-scan images with a depth scale to the right part of the picture. 4b) Corresponding average $C$-scan projected damaged area plotted against the energy applied during impact and quasi-static indentation (QSI) tests - vertical bars refer to the standard deviation between measurements. For colour interpretation refer to online version of this manuscript.

Figure 5. $\mu$ CT cross-sections of non-damaged THIN, V1 and V2 specimens.

Figure 6. Epifluorescence cross-sections of non-damaged V1 and V2 specimens.

Figure 7. $\mu C T$ cross-sections of THIN, $\mathrm{V} 1$ and $\mathrm{V} 2$ specimens indented at $\mathrm{d}=4 \mathrm{~mm}$. The centre of impact is indicated with a cross, (iii) is the tensile crack. The rest of damage mechanisms are detailed in Figure 8.

Figure 8. 3D representations of the damage mechanisms of THIN, V1 and V2 specimens indented at $\mathrm{d}=\mathbf{4} \mathrm{mm}$, (i) is the shear crack, (ii) is the crack initiated near NCF stitching locations (*) (NB: As this mechanism is located well away from the centre of impact it is not indicated in the Figure 7, (iv) is the small delamination below the centre of impact, (v) is the intra-resin crack and (vi) is the delamination away from the centre of impact.

Figure 9. $\mu \mathrm{CT}$ cross-sections of THIN, V1 and V2 specimens indented at $\mathrm{d}=4.4 \mathrm{~mm}$. The centre of impact is indicated with a cross.

Figure 10. $\mu C T$ cross-sections of THIN, V1 and V2 specimens indented at $d=5.24 \mathrm{~mm}$. The centre of impact is indicated with a cross, (viii) is fibre failure.

Figure 11. $\mu \mathrm{CT}$ cross-sections of THIN, V1 and V2 representative specimens impacted at $10 \mathrm{~J}$. The impacted centre is indicated with a cross.

Figure 12. $\mu \mathrm{CT}$ cross-sections of THIN, V1 and V2 representative specimens impacted at $14 \mathrm{~J}$. The impacted centre is indicated with a cross.

Figure 13a) Through-the-width failure of a $2.16 \mathrm{~mm}$ thick specimen impacted at $10 \mathrm{~J}$. 13b) CAI strength of pristine and impacted THIN, V1 and V2 specimens. The smaller markers refer to the strength of individual coupons, whereas the bigger ones stand for the average values. 


\section{Tables}

Table 1. Stacking sequences and test matrix. Bi-angle NCF layers are indicated with parenthesis. $V_{i}(i=1,2)$ refers to the incorporation of a non-woven veil.

\begin{tabular}{|c|c|c|c|c|c|c|c|c|c|}
\hline \multirow{3}{*}{ Name } & \multirow{3}{*}{ Stacking Sequence } & \multicolumn{8}{|c|}{ Number of specimens tested } \\
\hline & & \multicolumn{2}{|c|}{ Impact } & \multicolumn{3}{|c|}{ CAI } & \multicolumn{3}{|c|}{ QSI } \\
\hline & & $10 \mathrm{~J}$ & $14 \mathrm{~J}$ & $0 \mathrm{~J}$ & $10 \mathrm{~J}$ & $14 \mathrm{~J}$ & $\mathrm{~d}=4 \mathrm{~mm}$ & $\mathrm{~d}=4.4 \mathrm{~mm}$ & $\mathrm{~d}=5.24 \mathrm{~mm}$ \\
\hline THIN & {$[(45 / 0) /(-45 / 90)]_{4 S}$} & 3 & 5 & 2 & 3 & 5 & 1 & 1 & 1 \\
\hline $\mathrm{V} 1$ & {$\left[\left(45 / \mathrm{V}_{1} / 0\right) / \mathrm{V}_{1} /\left(-45 / \mathrm{V}_{1} / 90\right) / \mathrm{V}_{1}\right]_{4 \mathrm{~S}}$} & 3 & 4 & 2 & 3 & 4 & 1 & 1 & 1 \\
\hline $\mathrm{V} 2$ & {$\left[\left(45 / \mathrm{V}_{2} / 0\right) / \mathrm{V}_{2} /\left(-45 / \mathrm{V}_{2} / 90\right) / \mathrm{V}_{2}\right]_{4 \mathrm{~S}}$} & 3 & 5 & 2 & 3 & 5 & 1 & 1 & 1 \\
\hline
\end{tabular}


Table 2. $\mu \mathrm{CT}$ inspection parameters depending on the width of the sample inspected.

\begin{tabular}{ccccccc}
\hline Test & $\begin{array}{c}\text { Sample } \\
\text { width 'x' } \\
(\mathrm{mm})\end{array}$ & $\begin{array}{c}\text { Exposure } \\
\text { time } \\
(\mathrm{ms})\end{array}$ & $\begin{array}{c}\mathrm{V} \\
(\mathrm{kV})\end{array}$ & $\begin{array}{c}\mathrm{I} \\
(\mu \mathrm{A})\end{array}$ & $\begin{array}{c}\text { Voxel } \\
\text { size } \\
(\mu \mathrm{m})\end{array}$ & $\begin{array}{c}\text { Field of view } \\
(\mathrm{mm})\end{array}$ \\
\hline $\begin{array}{c}\text { Non-tested specimens/QSI at d= } \\
\text { 4 and d= 4.4 mm }\end{array}$ & $9-10 \mathrm{~mm}$ & 1500 & 55 & 80 & 5 & 11.2 \\
QSI at d= 5.24 mm & $30 \mathrm{~mm}$ & 1200 & 60 & 70 & 7 & 15.7 \\
Impact at 10 J & Not cut & 2500 & 70 & 75 & $11 / 6.5$ & $24.6 / 14.6^{\mathrm{a}}$ \\
Impact at 14 J & Not cut & 2500 & 70 & 75 & $14 / 10$ & $31.4 / 22.4^{\text {a }}$ \\
\hline
\end{tabular}

${ }^{a}$ Global or detailed inspections to assess the entire damage scenario or a representative zone centred at the site of impact.

Table 3. Value of the force local maximums $\left(F_{i}\right.$ and $\left.F_{Q}\right)$ and magnitude of the associated load-drops developed in the load-displacement curves of impacted and indented THIN, V1 and V2 specimens.

\begin{tabular}{|c|c|c|c|c|c|c|}
\hline \multirow[t]{3}{*}{ Material } & \multicolumn{6}{|c|}{ Test } \\
\hline & \multicolumn{2}{|c|}{ Impact at $10 \mathrm{~J}$} & \multicolumn{2}{|c|}{ Impact at $14 \mathrm{~J}$} & \multicolumn{2}{|r|}{ QSI } \\
\hline & $\mathrm{F}_{\mathrm{i}}(\mathrm{kN})$ & Load drop (\%) & $\mathrm{F}_{\mathrm{i}}(\mathrm{kN})$ & Load drop (\%) & $\mathrm{F}_{\mathrm{Q}}(\mathrm{kN})$ & Load drop (\%) \\
\hline THIN & 3.24 & 21 & 3.27 & 21 & 3.32 & Multiple \\
\hline V1 & 3.15 & 13 & 3.23 & 10 & 3.1 & Multiple \\
\hline V2 & 3.32 & 6 & 3.13 & 10 & None & None \\
\hline
\end{tabular}



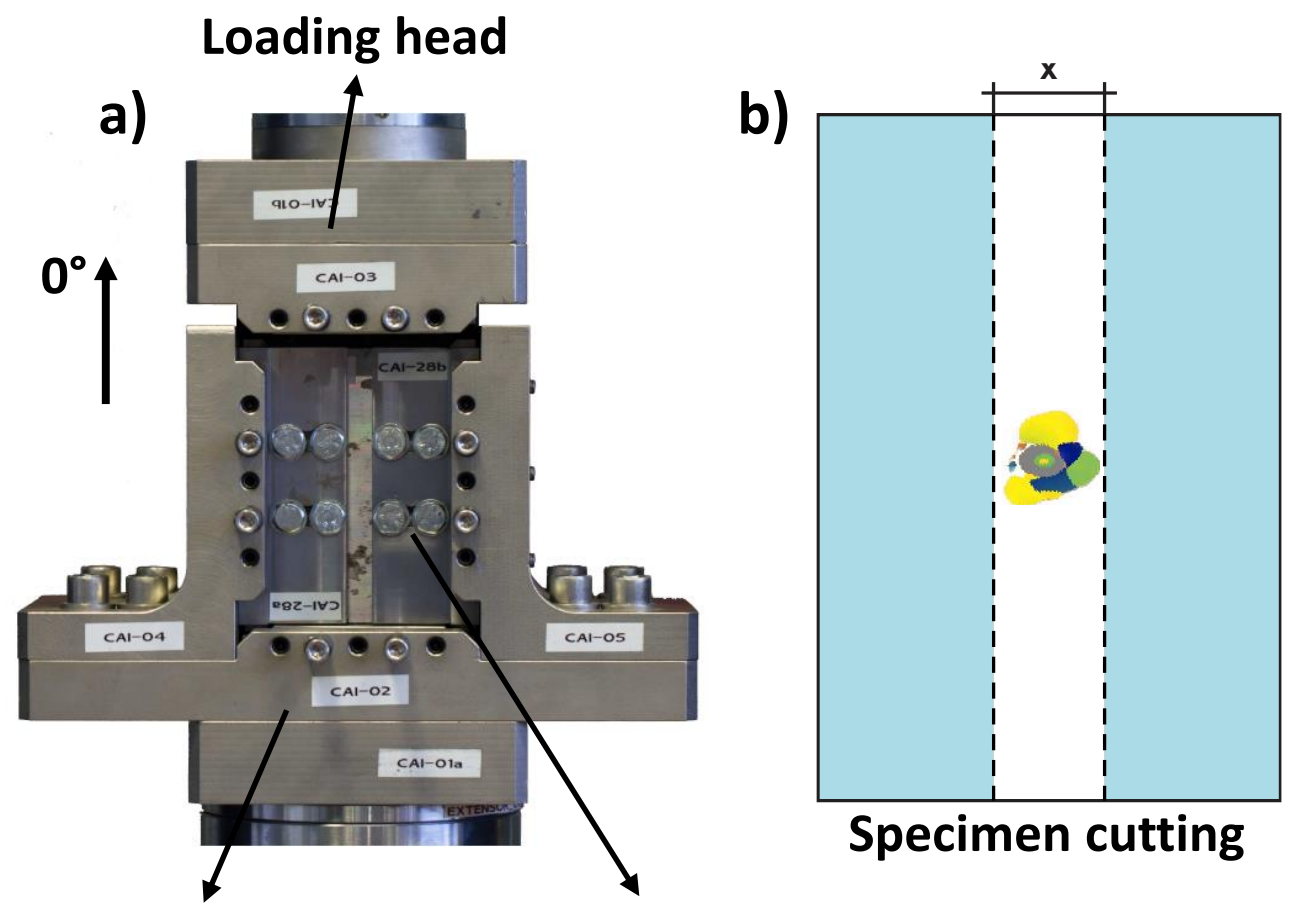

Base assembly Antibuckling plate

Figure 1a) Non-standard compression after impact (CAI) test fixture (adopted from [32]). 1b) Cutting of indented specimens prior to inspection with $\mu \mathrm{CT}$. 

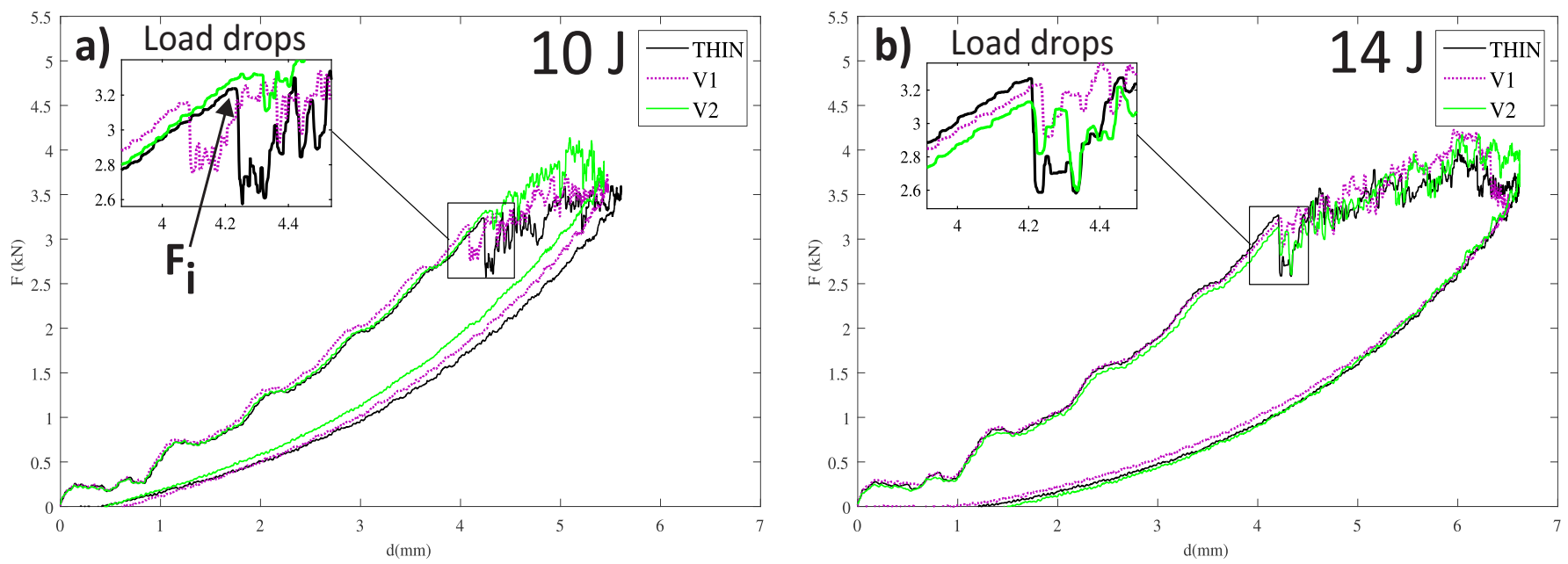

Figure 2. Load-displacement curves of representative THIN, V1 and V2 specimens impacted at a) $10 \mathrm{~J}$ and b) $14 \mathrm{~J}$. For colour interpretation refer to online version of this manuscript. 
a)

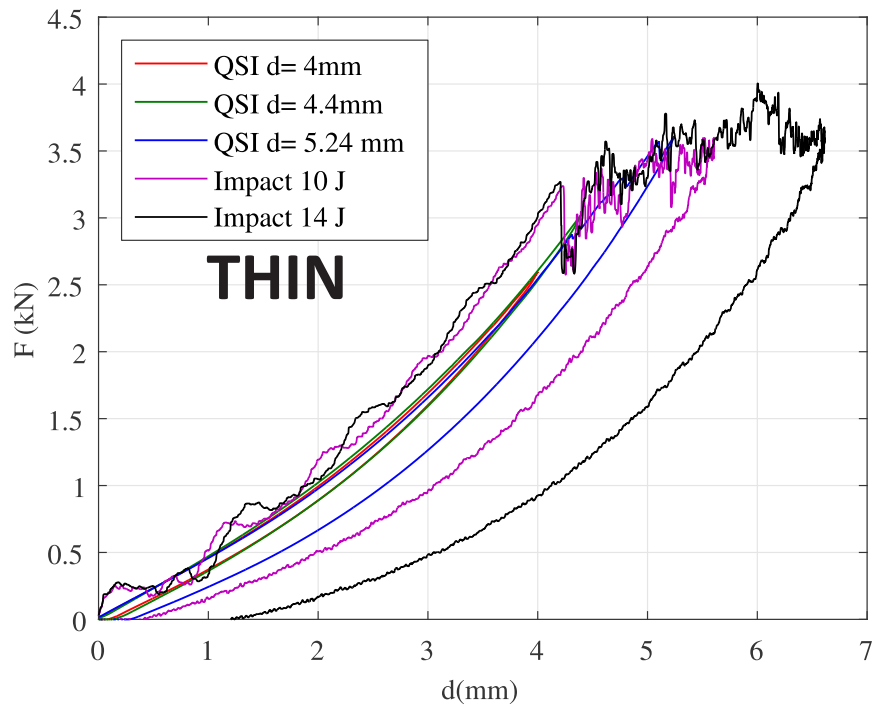

c)

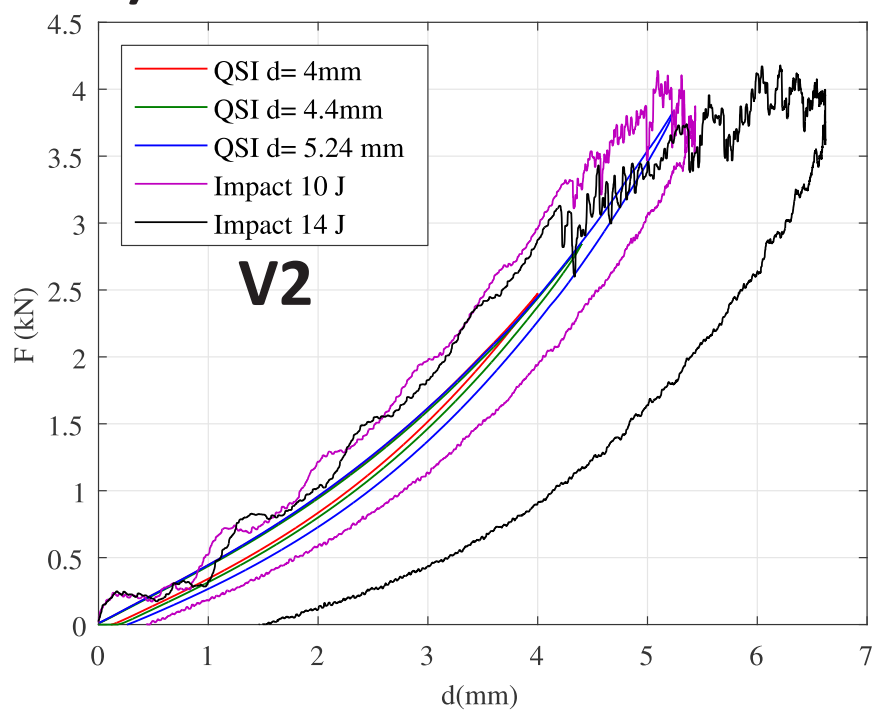

b)

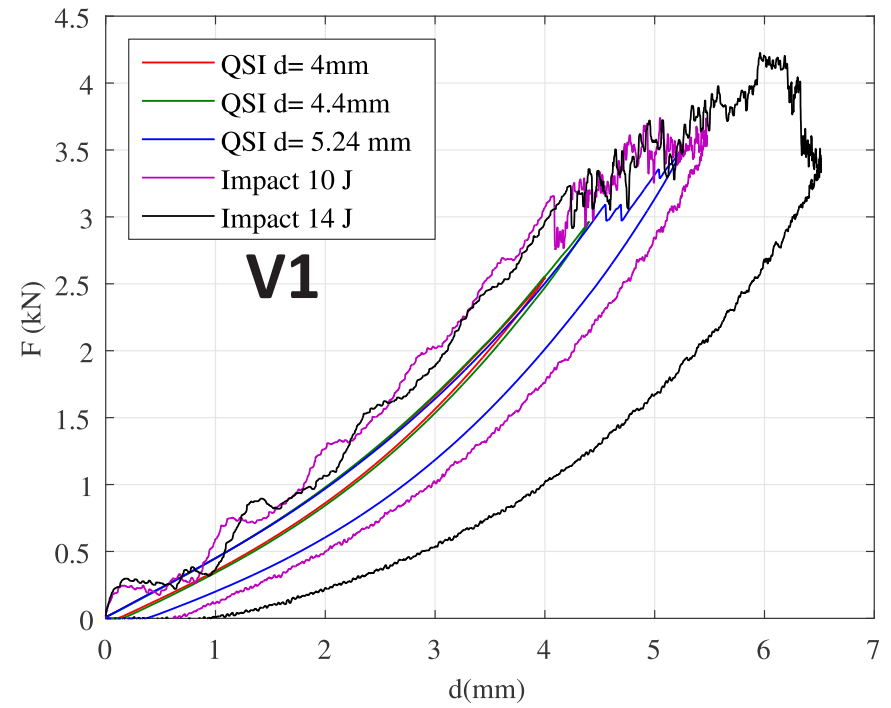

d) QSI at d= $5.24 \mathrm{~mm}$

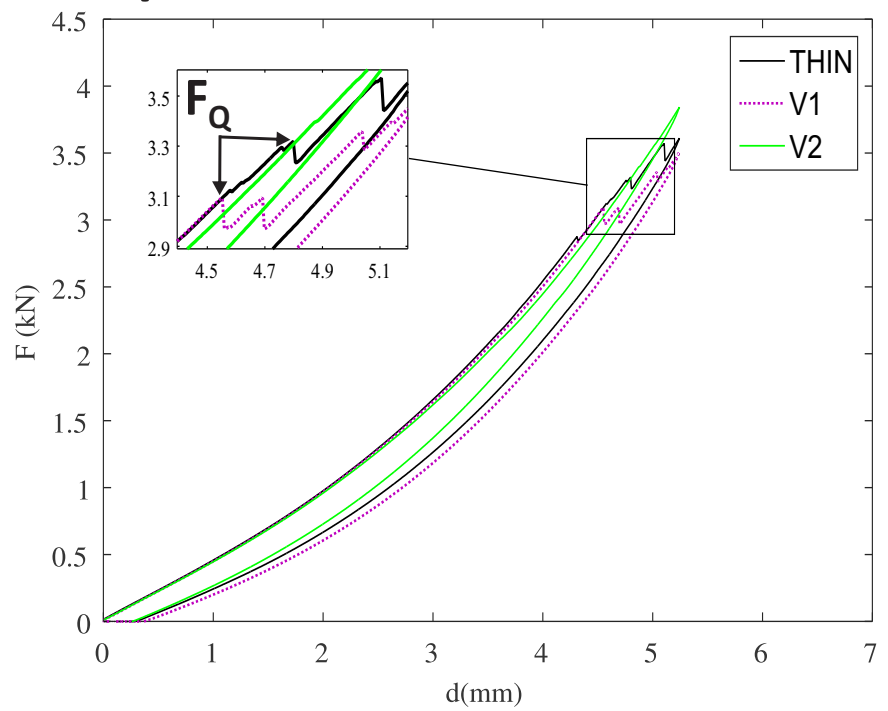

Figure 3. Load-displacement curves of representative impacted and indented specimens a) THIN b) V1 c) V2. 3d) Load-displacement curves of THIN, V1 and V2 specimens indented at $d=5.24 \mathrm{~mm}$. For colour interpretation refer to online version of this manuscript. 


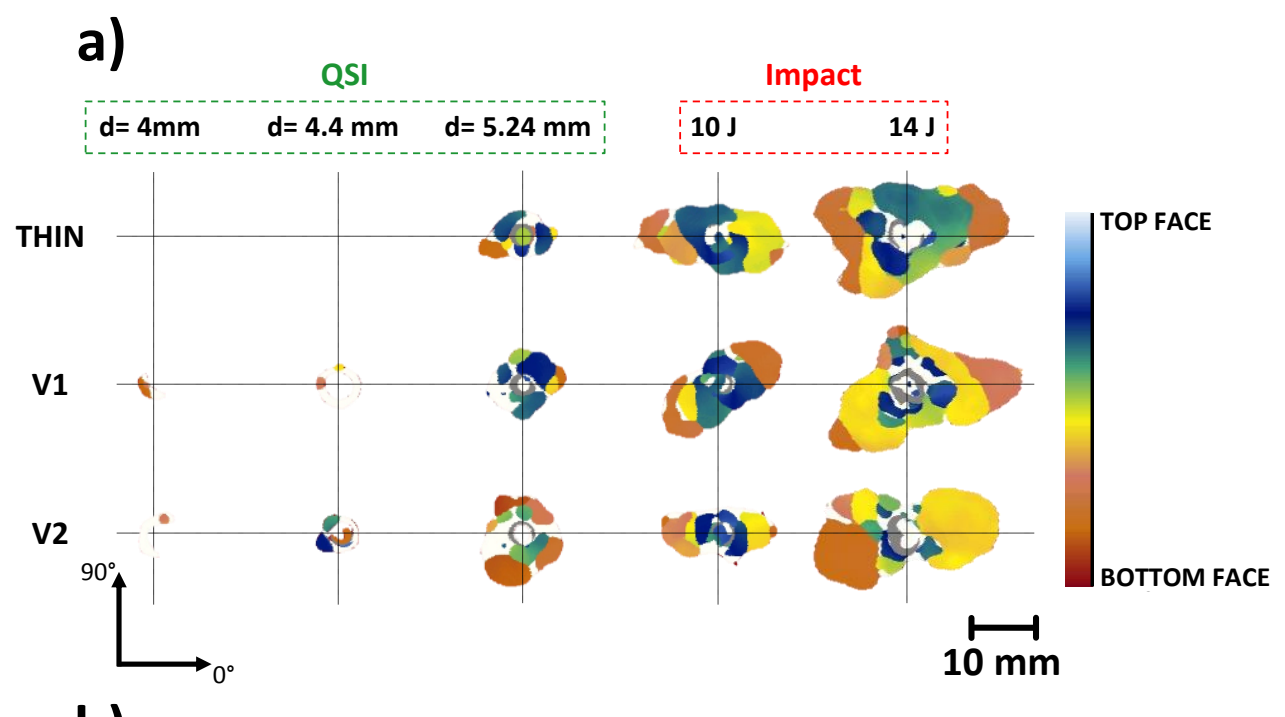

b)

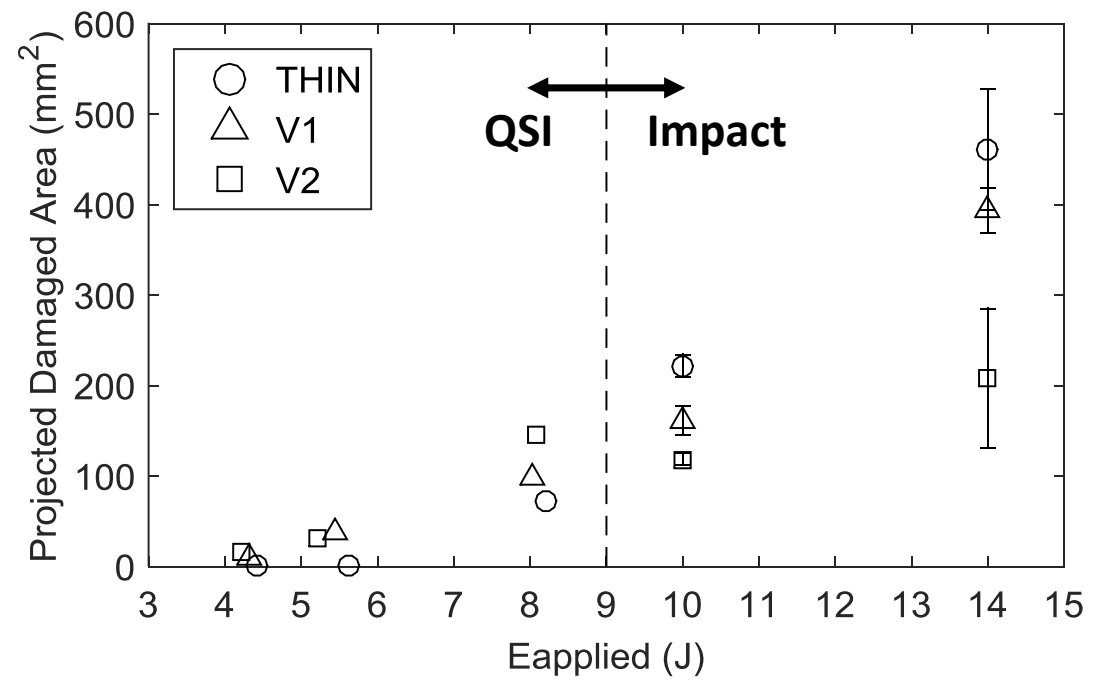

Figure 4a) Ultrasonic C-scan images with a depth scale to the right part of the picture. 4b) Corresponding average C-scan projected damaged area plotted against the energy applied during impact and quasi-static indentation (QSI) tests - vertical bars refer to the standard deviation between measurements. For colour interpretation refer to online version of this manuscript. 


\section{Microstructure of non-damaged specimens}
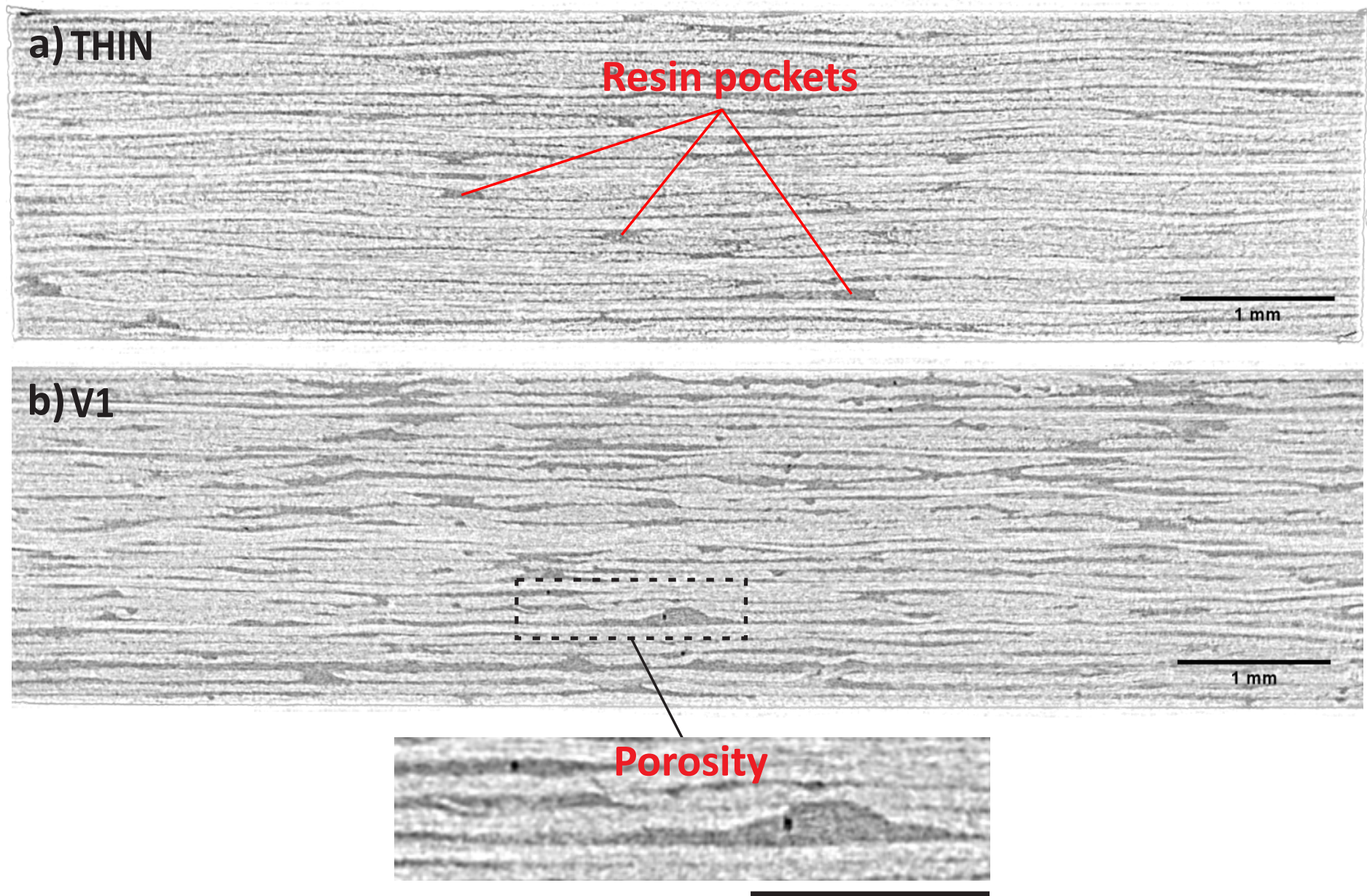

\section{$0.5 \mathrm{~mm}$}

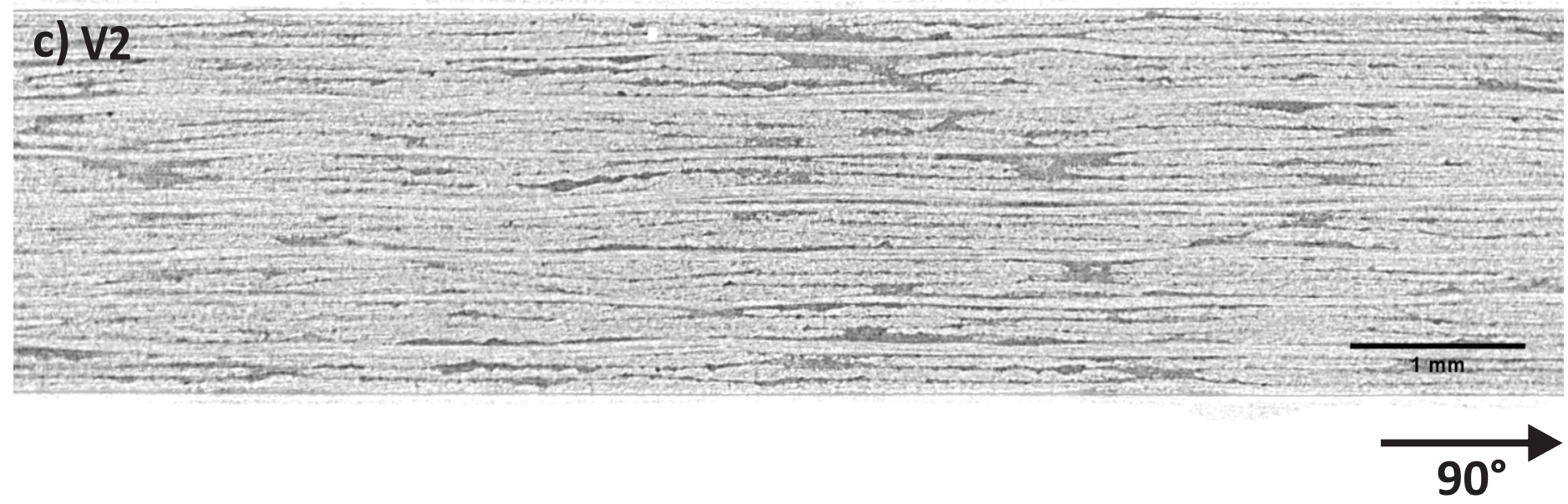

Figure 5. $\mu \mathrm{CT}$ cross-sections of non-damaged THIN, V1 and V2 specimens. 
a) V1

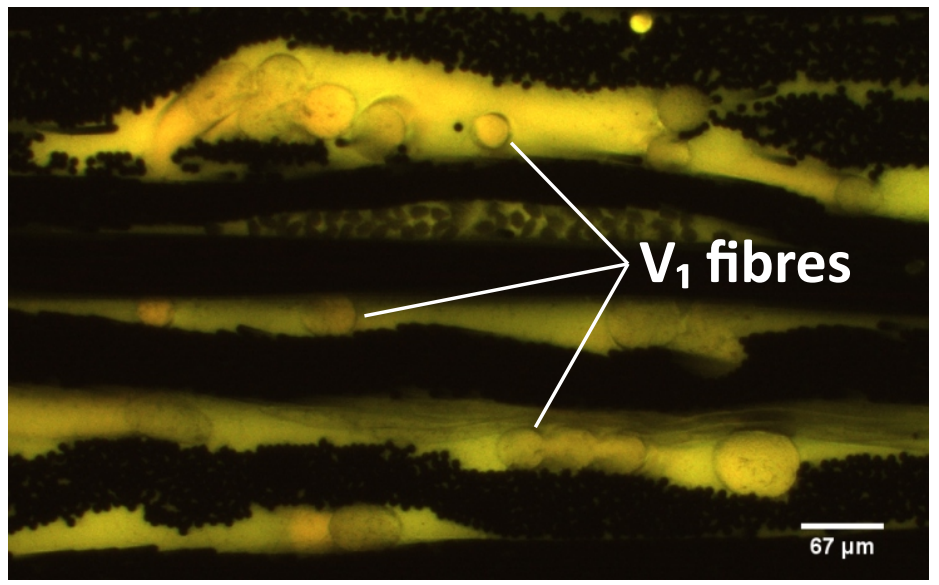

b) V2

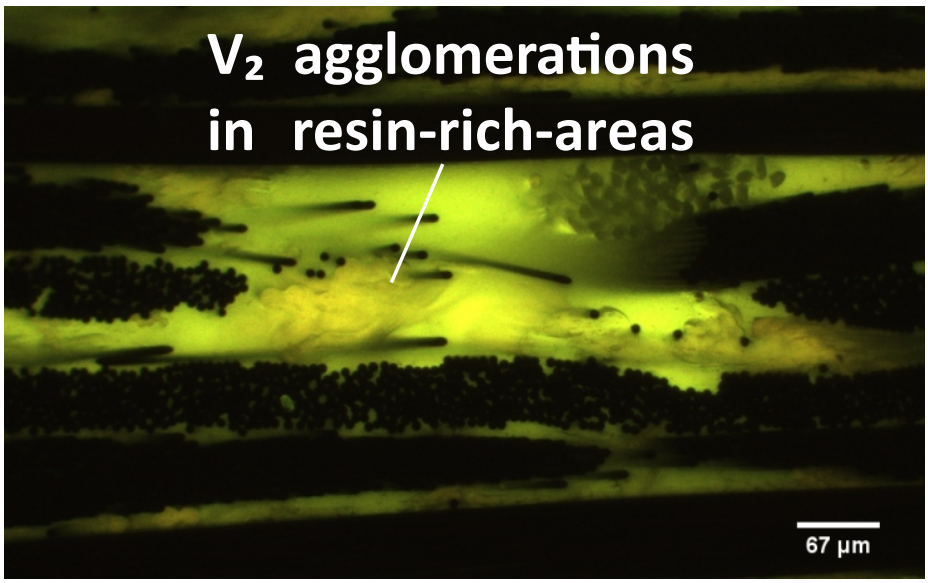

Figure 6. Epifluorescence cross-sections of non-damaged V1 and V2 specimens. 


\section{QSI at $d=4 \mathrm{~mm}$}
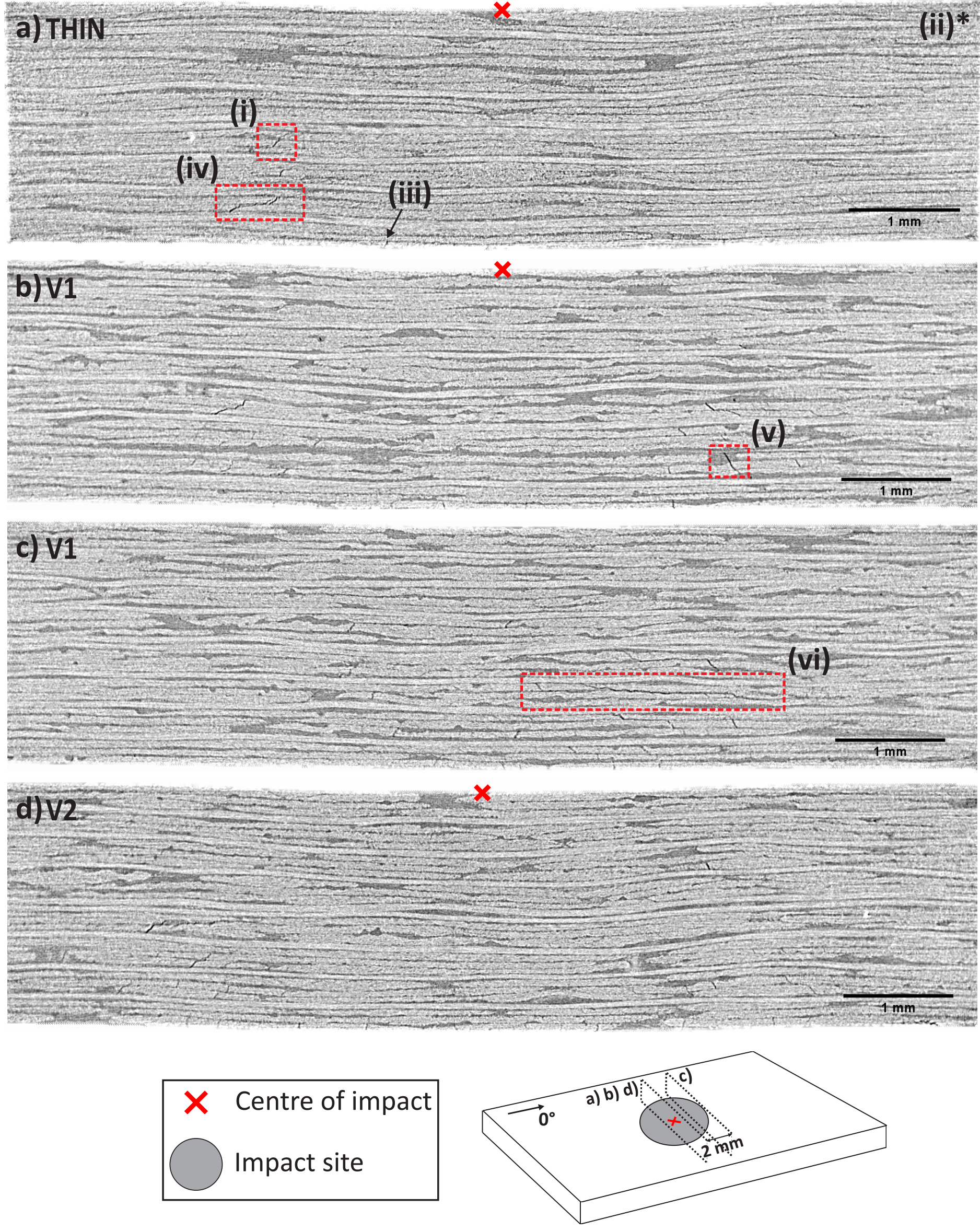

Figure 7. 
3D damage mechanisms

(i) THIN

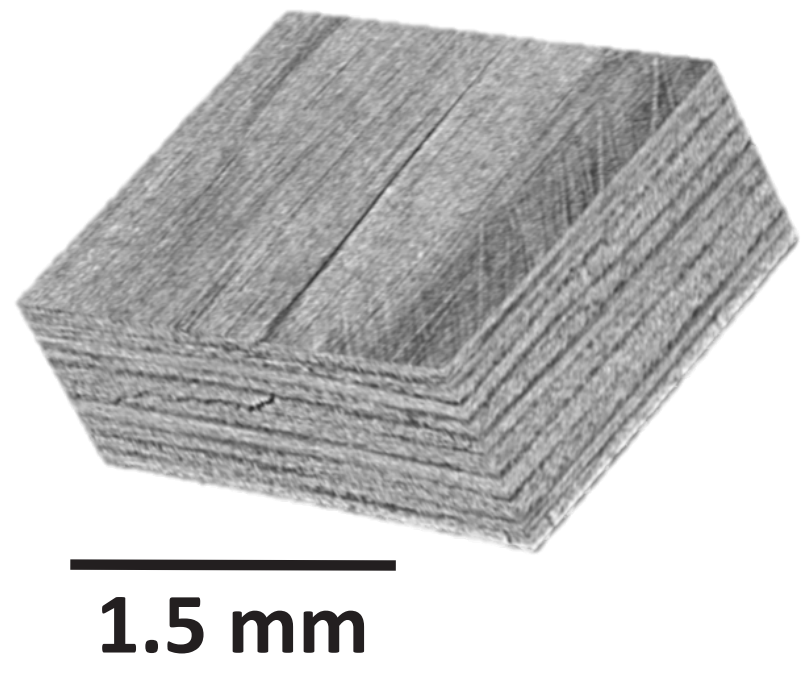

(ii) THIN

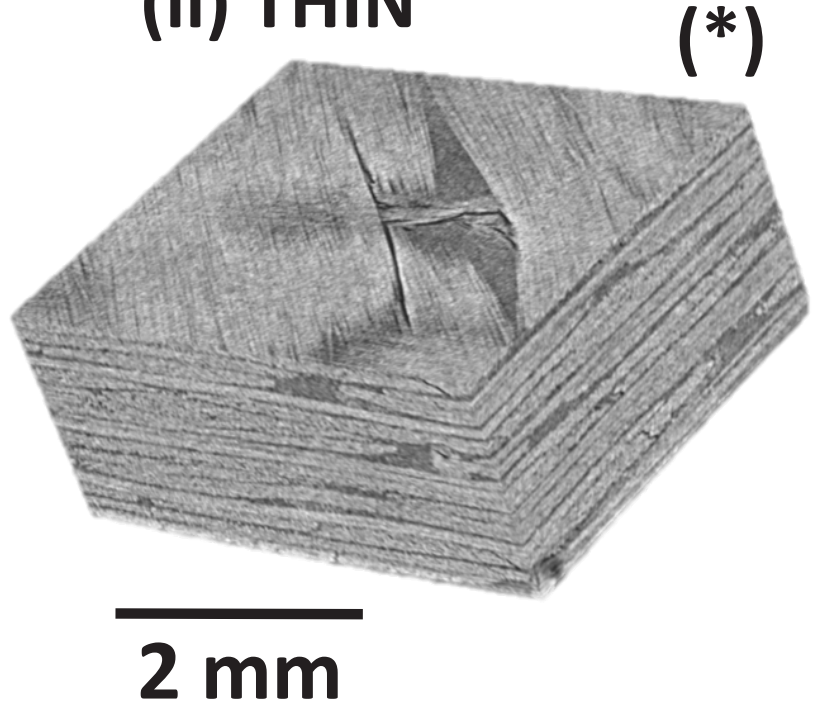

(vi) V1

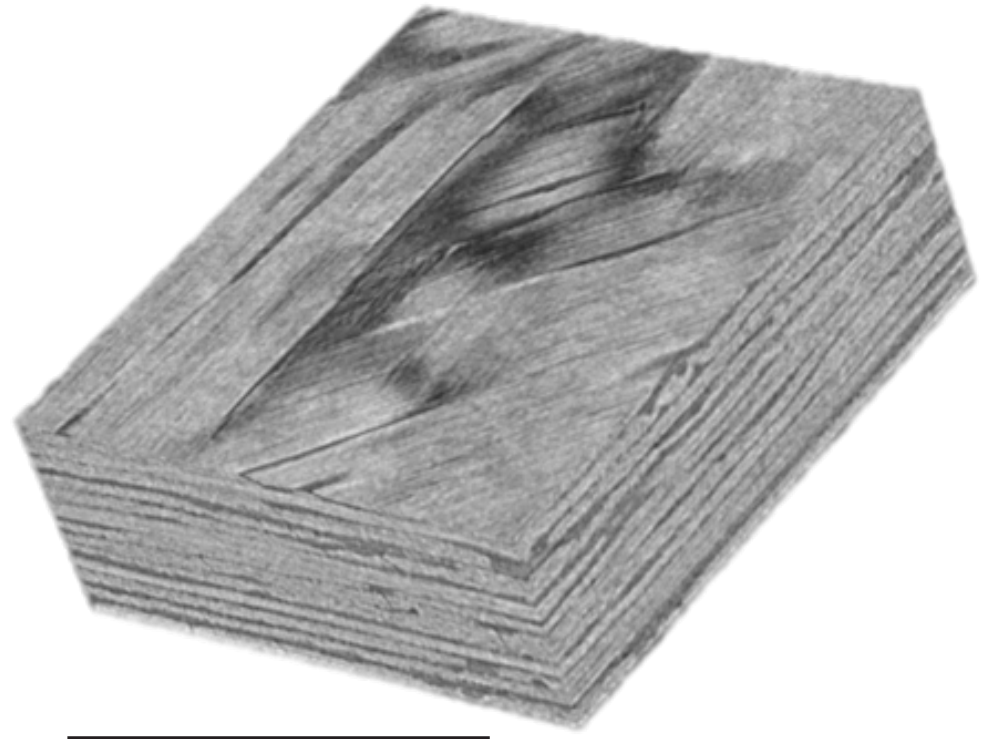

(iv) THIN

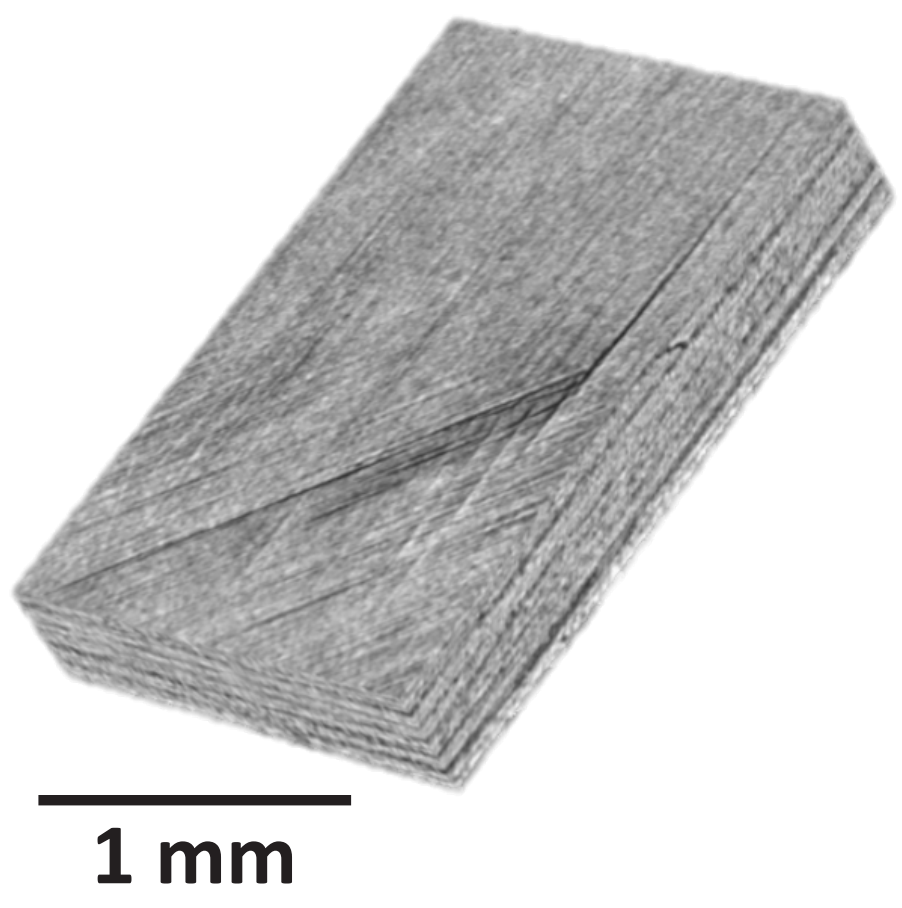

(v) V1
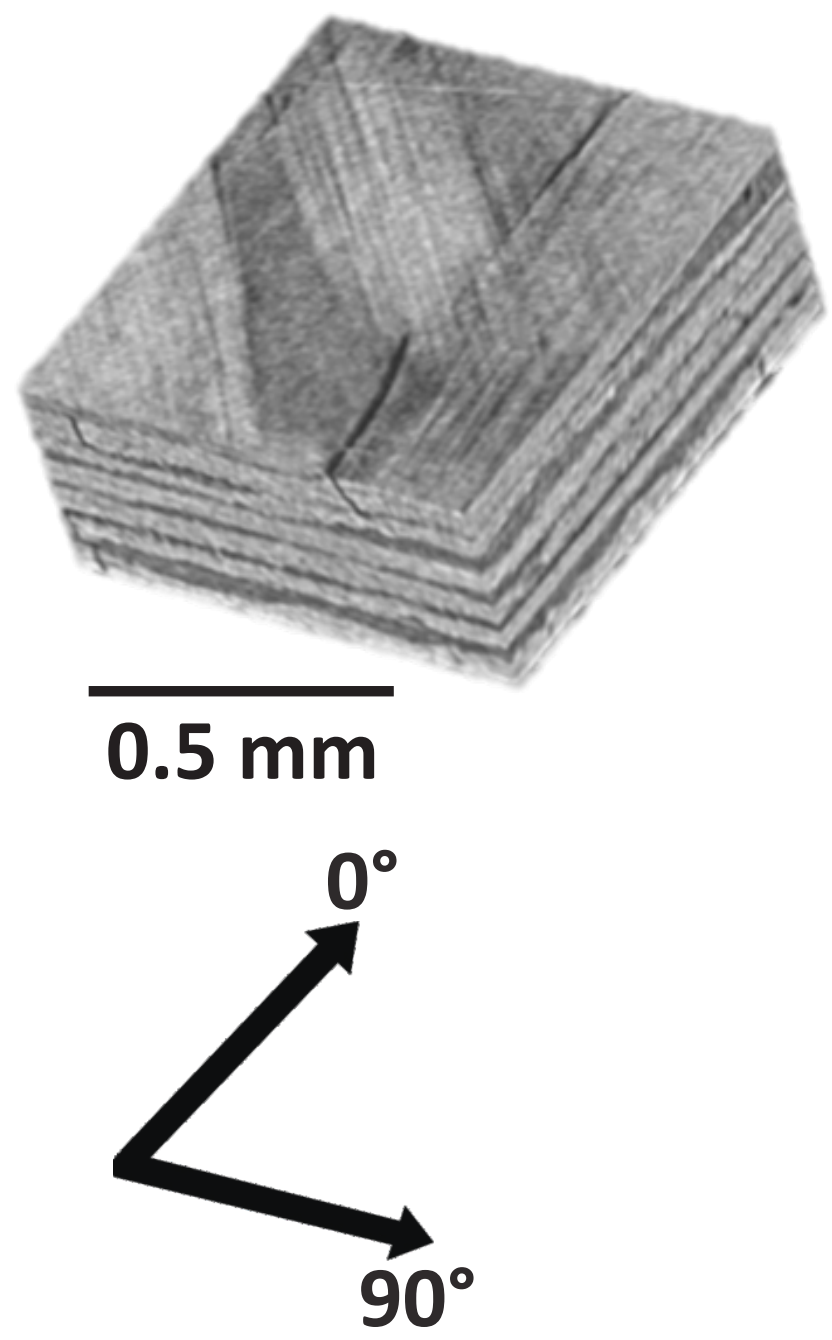

$1 \mathrm{~mm}$

Figure 8. 


\section{QSI at $d=4.4 \mathrm{~mm}$}
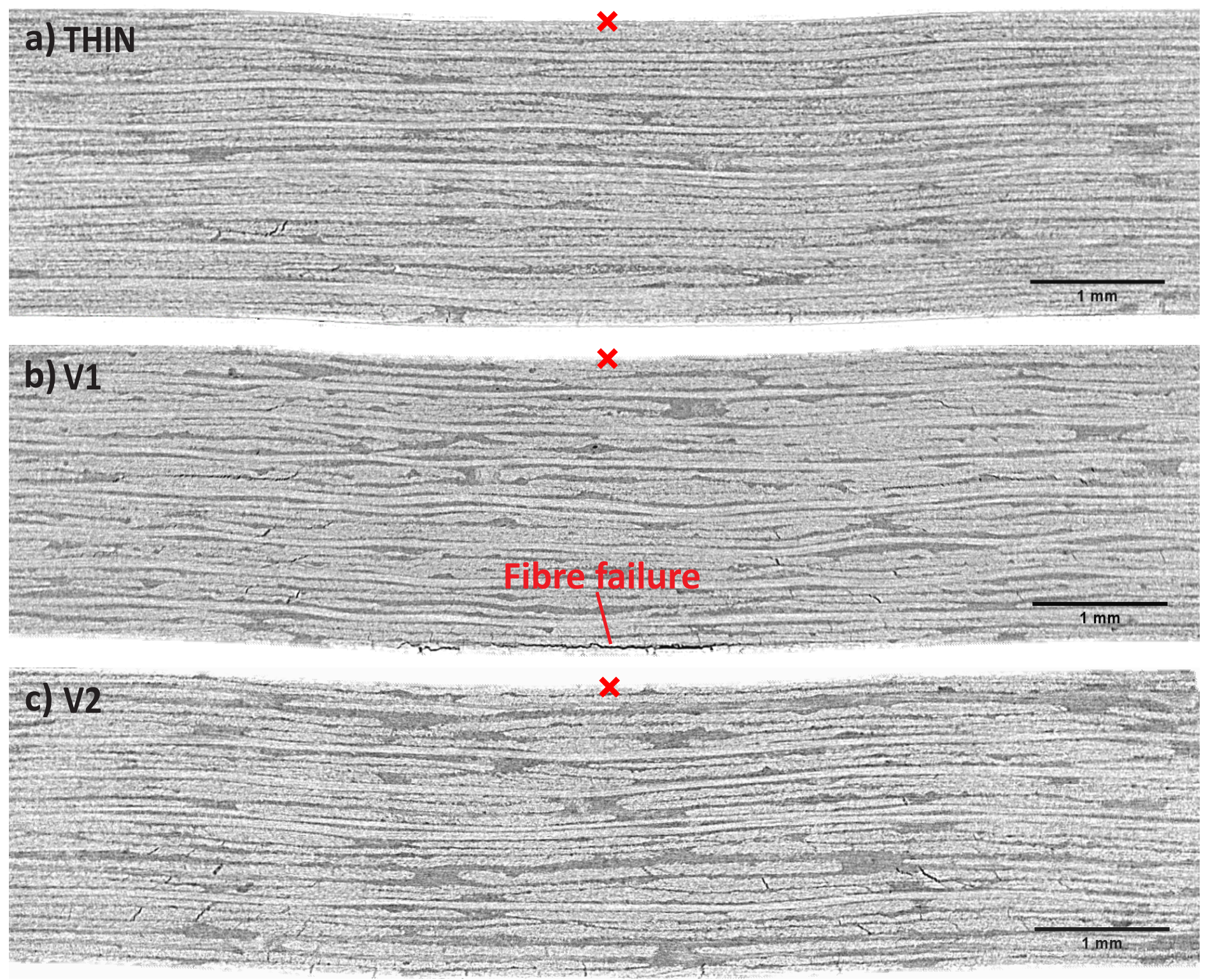

Figure 9. 


\section{QSI at $d=5.24 \mathrm{~mm}$}
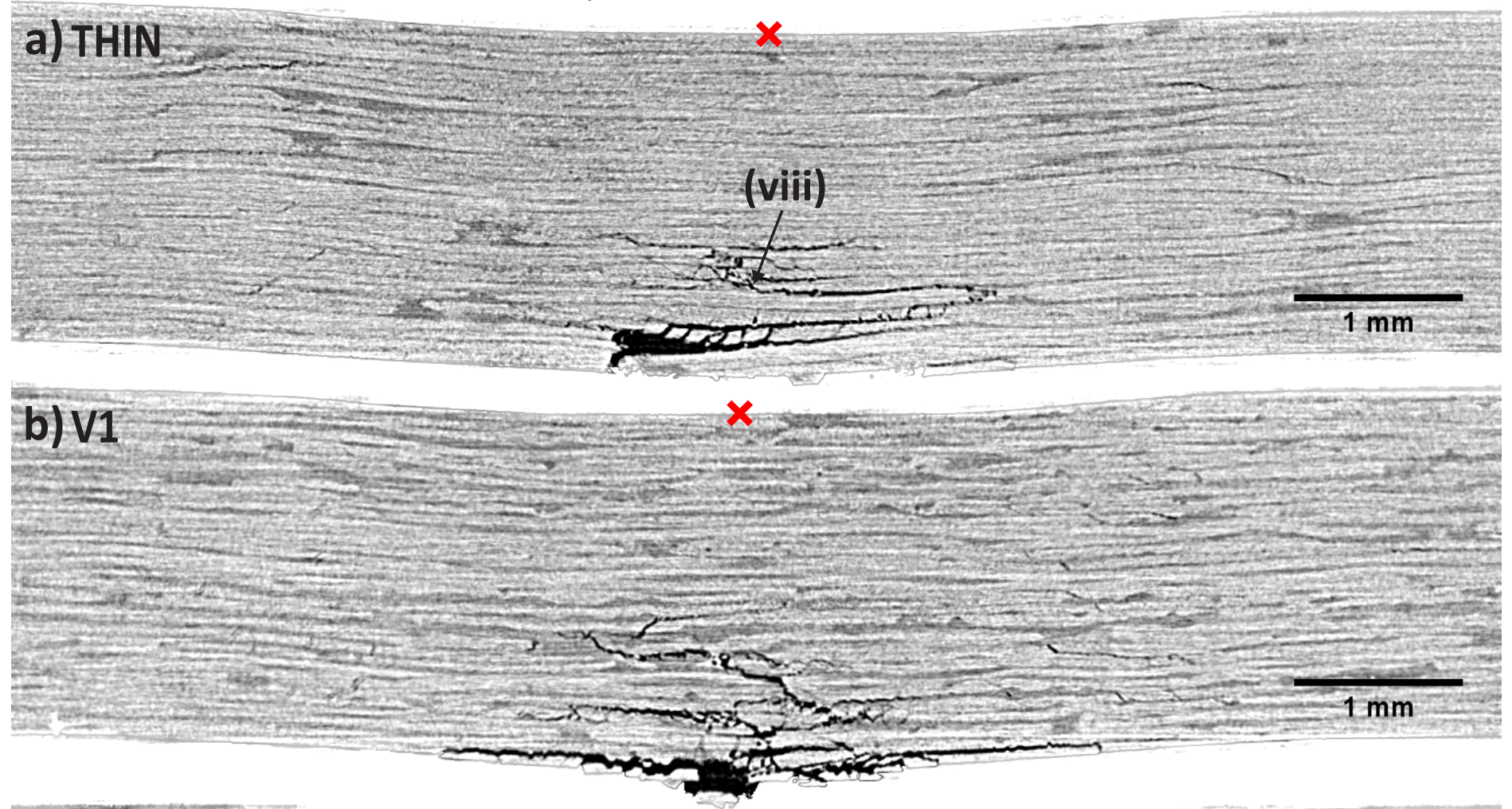

\section{c) V2}

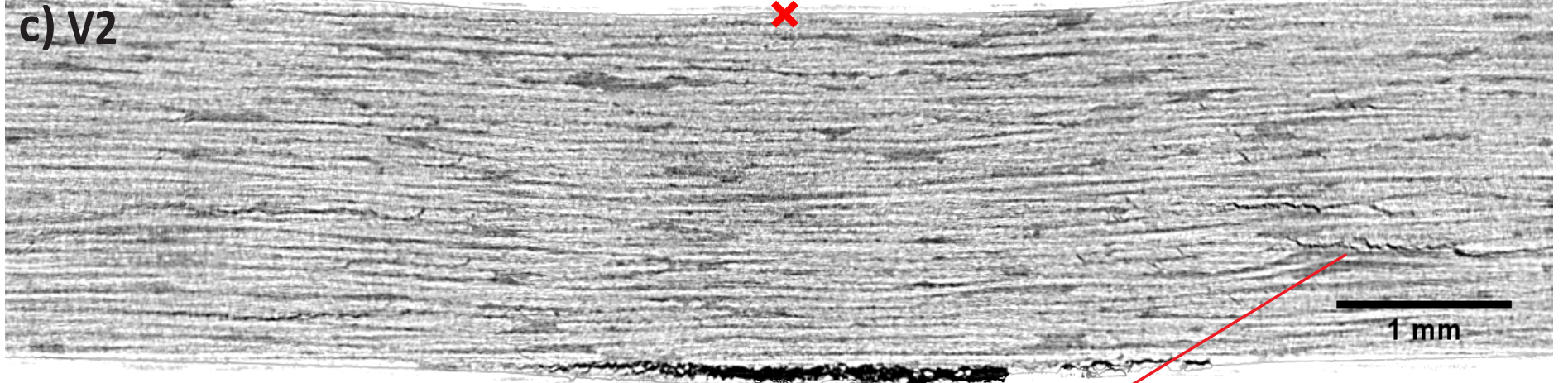

d)

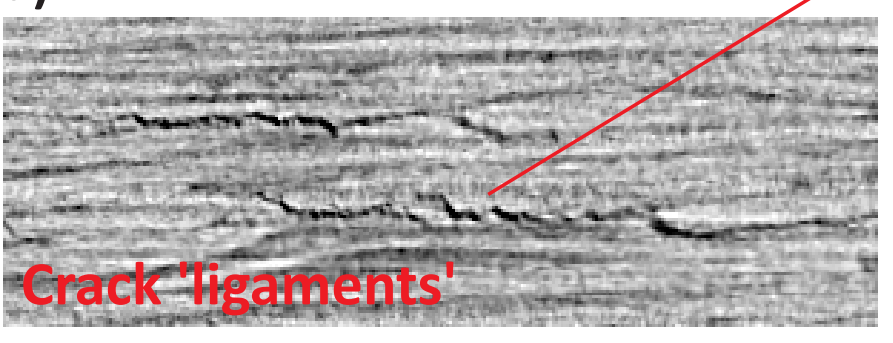

$0 . \overline{\mathrm{mm}}$

Figure 10. 


\section{$10 \mathrm{~J}$ impact}
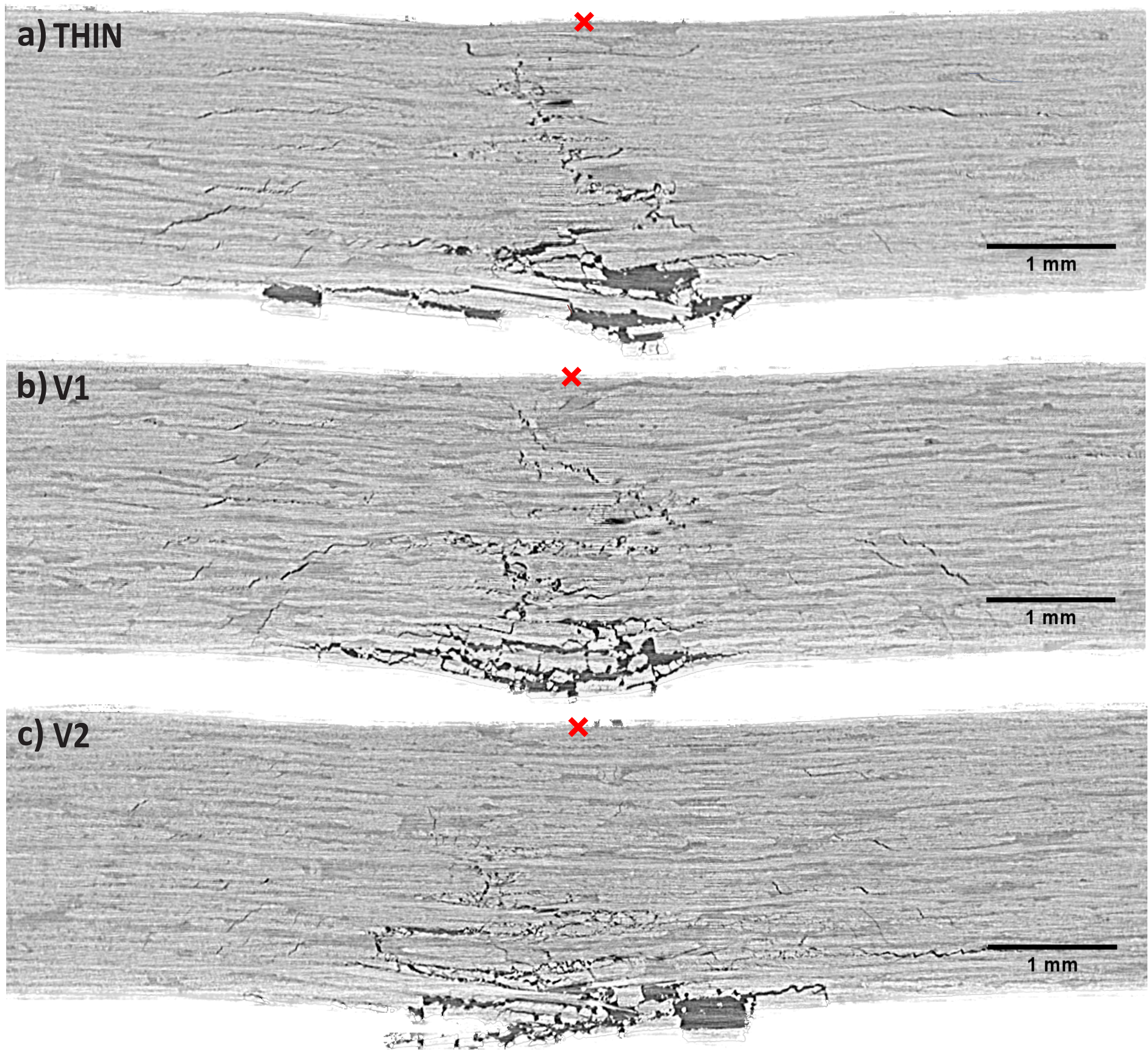

Figure 11. 


\section{$14 \mathrm{~J}$ impact}

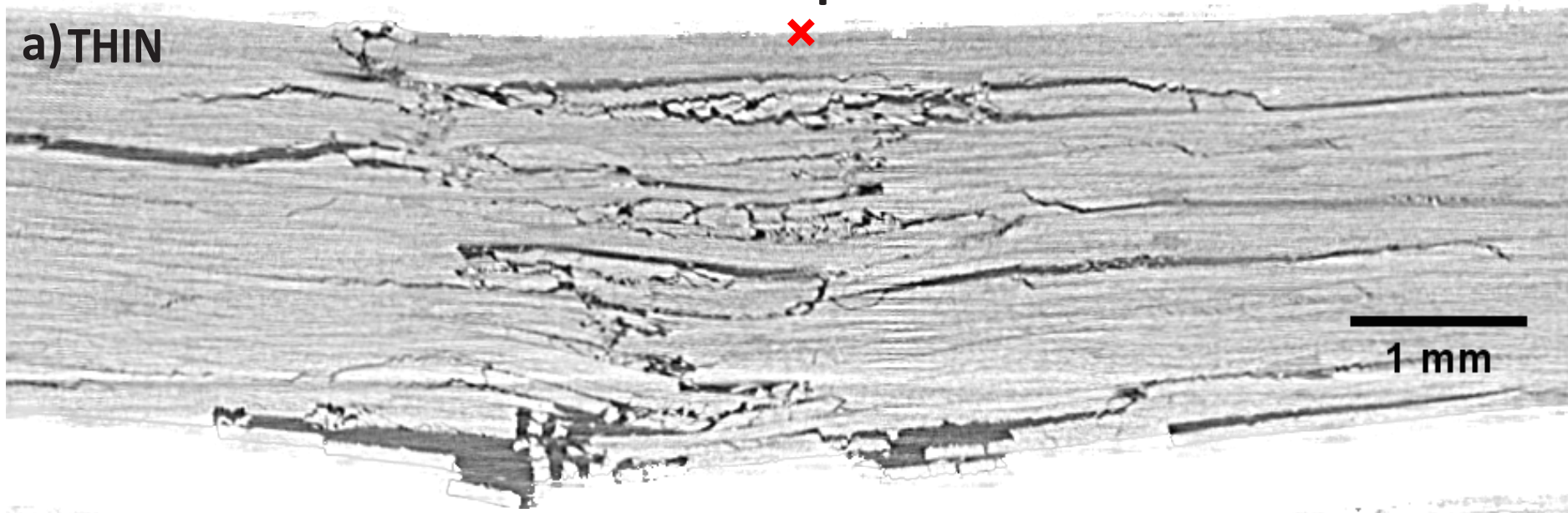

b) V1

$x$
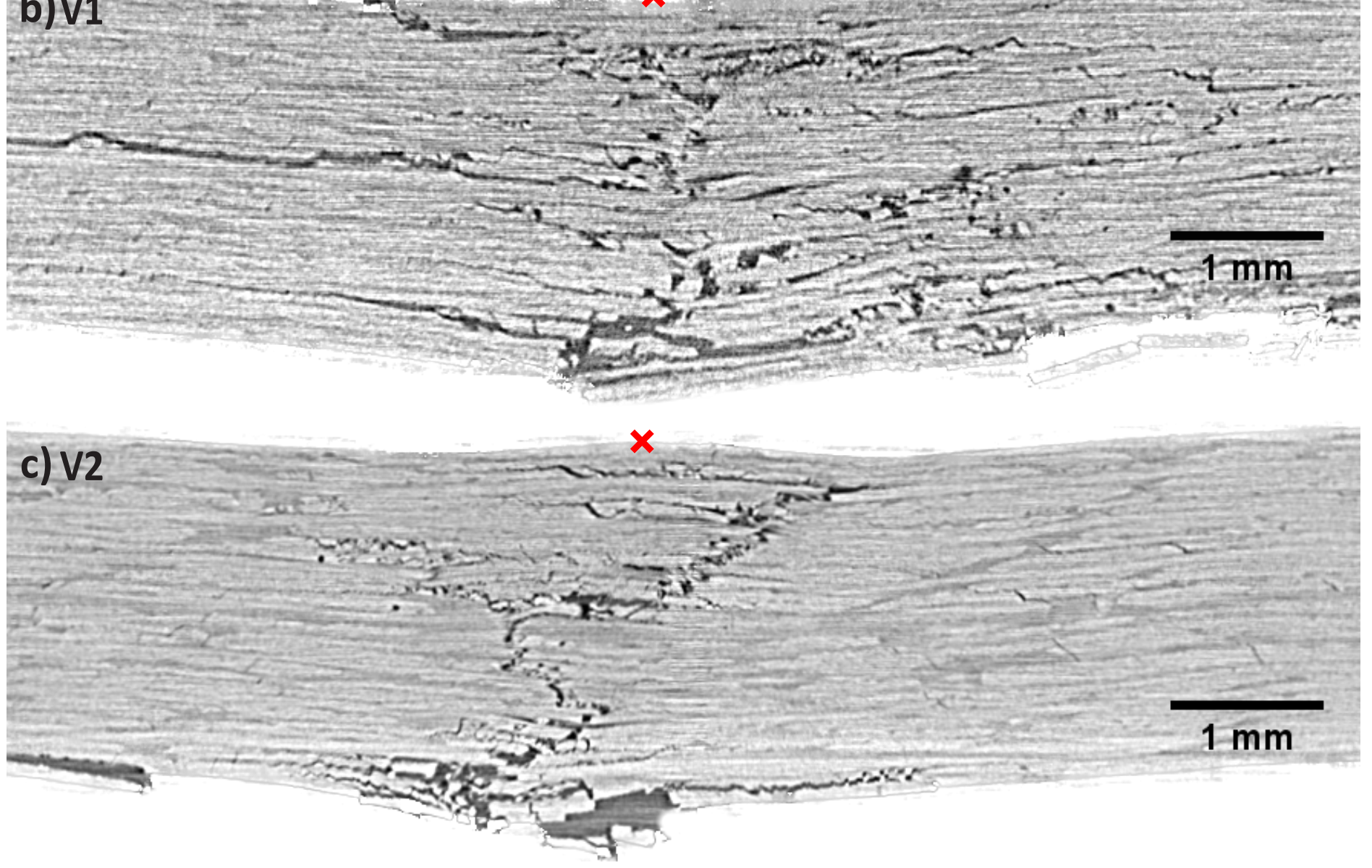

Figure 12. 
a)

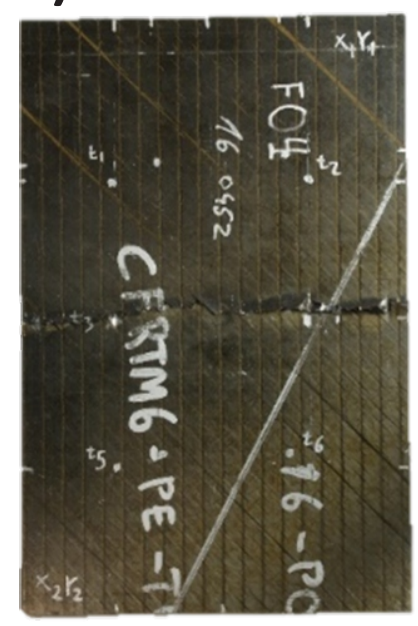

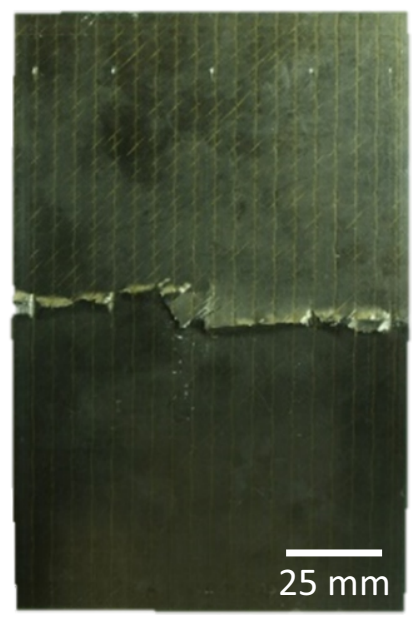

b)

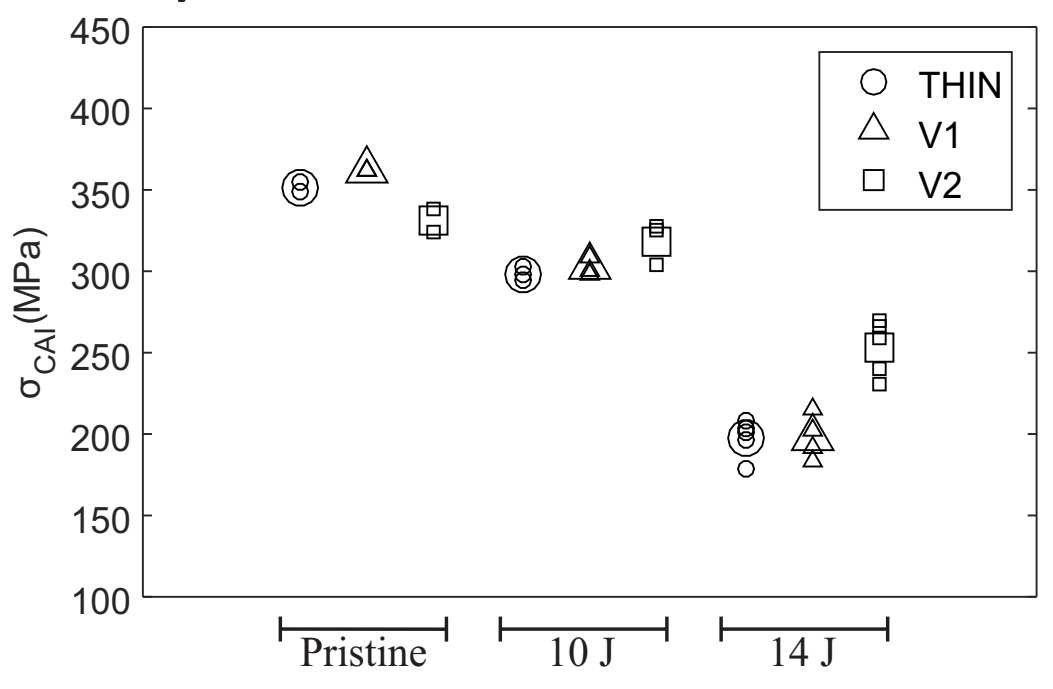

Figure 13a) Through-the-width failure of a $2.16 \mathrm{~mm}$ thick specimen impacted at $10 \mathrm{~J}$. 13b) CAI strength of pristine and impacted THIN, V1 and V2 specimens. The smaller markers refer to the strength of individual coupons, whereas the bigger ones stand for the average values. 